KRZYSZTOF R. PROKOP - GLIWICE

\title{
WYPISY ŹRÓDLOWE DO BIOGRAFII POLSKICH BISKUPÓW I OPATÓW Z CZASÓW RZECZYPOSPOLITEJ OBOJGA NARODÓW ORAZ NIEWOLI NARODOWEJ DOBY ZABORÓW (XVI - XIX w.)
}

\author{
(cz. VII)
}

Dążąc do - na ile to możliwe - pewnego pogrupowania świadectw źródłowych, prezentowanych w ramach naszego cyklu, w obecnej jego części przedkładamy uwadze osób sięgających po owe materiały zapiski odnoszące się przede wszystkim do stolic biskupich w Chełmży i we Fromborku, a więc diecezji chełmińskiej oraz warmińskiej, w wiekach XVI-XIX. Zaczerpnięte zostały one ze staropolskich zabytków źródłowych, przechowywanych w Archiwum Archidiecezjalnym w Olsztynie i Archiwum Diecezjalnym w Pelplinie, w których obu piszący te słowa przeprowadził kwerendy. Skądinąd jednak są to kolekcje archiwalne bardzo zasobne i przy dalszych poszukiwaniach zapewne można tam będzie napotkać inne jeszcze świadectwa, które by zasługiwały na uwzględnienie w ramach niniejszej serii. Jak wszakże zostało to wyartykułowane niegdyś we wstepie edytorskim, poprzedzającym pierwszą część tego cyklu, w żadnym wypadku nie jest naszym zamiarem zinwentaryzowanie i wydanie drukiem wszystkich zachowanych zapisek, informujących o podstawowych faktach z curriculum vitae przedstawicieli wyższej hierarchii kościelnej z doby Rzeczypospolitej Obojga Narodów oraz z czasów porozbiorowych, gdyż najzwyczajniej wykracza to poza możliwości pojedynczego badacza, do tego stosowne poszukiwania prowadzącego niejako na marginesie innych poczynań na niwie naukowej. Nawet jednak i przy tego rodzaju niejako naturalnych ograniczeniach, podjęty trud wydaje się nie być bezowocny, zaś fakt, iż poprzednie odcinki Wypisów źródłowych doczekały się przywołania nawet w skądinąd wybiórczej z konieczności bibliografii przy biogramach niektórych biskupów w Encyklopedii Katolickiej (nie wspominając 
o poświęconych rozmaitej problematyce artykułach i przyczynkach), stanowi dodatkową przesłankę i argument, by ów cyk1 - mimo wszelkich przeszkód - kontynuować na gościnnych łamach półrocznika „Archiwa, Biblioteki i Muzea Kościelne".

Obok przeważających liczebnie świadectw z Pomorza Nadwiślańskiego oraz Warmii, w obecnym odcinku cyklu znalazło się też kilka zapisek dotyczących ziem wschodnich dawnej Rzeczypospolitej. Znaczna część zachowanych zabytków piśmiennictwa, odnoszących się do dziejów tychże obszarów, dziś przechowywana jest poza aktualnymi granicami Polski, co niewątpliwie utrudnia badania, ale bynajmniej ich nie uniemożliwia, czego jednym z najświeższej daty dowodów jest wydany w roku 2008 trzeci tom Leksykonu zakonnic polskich epoki przedrozbiorowej s. Małgorzaty Borkowskiej z Żarnowca, poświęcony konwentom z terenów dawnego Wielkiego Księstwa Litewskiego oraz ziem ruskich Korony Polskiej ${ }^{1}$. Podobnie, jak poprzednie z woluminów owego nadzwyczaj cennego słownika biograficznego, zapewne niejednokrotnie będzie on pojawiał się w zawartej w przypisach naszego cyklu bibliografii, odnoszącej się do faktów z życia poszczególnych postaci (w tym konkretnym przypadku ksień i opatek). Wypada żywić nadzieję, że w niedoległej przyszłości ukażą się drukiem kolejne tego rodzaju kompendia prozpopograficzne.

\section{Archiwum Archidiecezjalne w Olsztynie (AAWO)}

AB Eb 81 - Liber anniversariorum exequiarum Collegiatae Ecclesiae Gudtstatensis [1486-1653];

AB H 37 - Archivum vetus et novum ecclesiae archipresbyteralis Heilsbergensis, ex variis historiae Prussiae scriptoribus a P.R.D. Georgio Adalberto Heide, canonico Culmensi, archipresbytero parocho Heilsbergensi, collectum [1326$-1764]$;

AB H 37a-Archivum vetus et novum ecclesiae archipresbyteralis Heilsbergensis [1326-1767/1768, 1813-1890];

AB H 42 - [Series episcoporum Varmiensium];

AB H 149 - [Liber ordinatorum 1801-1840];

AB H 150 - Liber connotationis pontificalium functionum [episcopi Josephi Aloisi Geritz].

\section{Archiwum Diecezjalne w Pelplinie (ADP)}

AKKCh A 16 - Aquila feliciter evolans ac sub auspiciis Illustrissimi, Excellentissimi, Reverendissimi Domini, Domini Mathiae Sołtyk, Dei et Apostolicae Se-

${ }^{1}$ M. Borkowska, Leksykon zakonnic polskich epoki przedrozbiorowej, t. 3: Wielkie Księstwo Litewskie i ziemie ruskie Korony Polskiej, Warszawa 2008. 
dis gratia episcopi Margaritensis, suffraganei, archidiaconi Culmensis, praepositi cathedralis Gnesnensis, Thorunensis, canonici Varmiensis, etc., etc., omnes in diaecesi Culmensi ordinatos gratiosissimis alis protegens [drugi tytut: Liber ordinatorum 1729-1749];

AKKCh A 46 - [Acta capituli Culmensis 1601-1644];

AKKCh A 47 - [Acta capitularia Culmensia ab anno 1690-1702];

AKKCh A 48 - Protocollon actorum capituli Culmensis sub auspiciis Excellentissimi, Illustrissimi et Reverendissimi Domini, Domini Theodori Potocki, episcopi Culmensis et Pomesaniae, anno 1705 inchoatorum [1705-1723];

AKKCh A 49 - Acta Venerabilis Capituli sede Culmensi vacante acticata, tum demum sub felici ingressu Illustrissimi et Reverendissimi Felicis in Kretkow Kretkowski, Dei et Apostolicae Sedis gratia episcopi Culmensis et Pomesaniae, sub praesidentia vero Illustrissimi et Reverendissimi Severini Szczuka, episcopi Joppensis, suffraganei, archidiaconi, etc. continuata [...] ab anno 1723 ad annum 1773 ;

C 25 - Acta acticata causarum Curiae Episcopalis Culmensis coram Excellentissimo, Illustrissimo et Reverendissimo Domino Casimiro de Szczuki Szczuka, episcopo Culmensi et Pomesaniae, partim coram Perillustri et Reverendissimo Domino Adamo Rostkowski, Sacrae Theologiae et Juris Utriusque doctore, praeposito Varsaviensi, Vladislaviensi [et] Plocensi canonico, Curiae eiusdem Illustrissimi episcopi causarum auditore et iudice generali in anno 1694 gesta et observata;

C 54a [V 23] - Liber ordinatorum ab Illustrissimo et Reverendissimo Domino, Domino Fabiano Francisco Pląskowski, Dei et Apostolicae Sedis gratia episcopo Martyropolitano, suffraganeo Culmensi, etc.;

C 67 - [Spis kościołów i duchowieństwa diecezji chełmińskiej i pomezańskiej 1785/1786] (tamże na końcu - przy braku ciagłej paginacji - Catalogus presbyterorum mortuorum sub regimine Illustrissimi, Reverendissimi ac Excellentissimi Domini comitis de Hohenzollern, episcopi Culmensis, etc. etc.)

\section{Archiwum Kapituly Metropolitalnej w Krakowie (AKapMK)}

KP 226 - Liber variarum ab urbe et aliis locis expeditionum originalium ad $\mathrm{Cu}-$ riam Episcopalem sub auspiciis Illustrissimi, Excellentissimi et Reverendissimi Domini, Domini Antoni Sebastiani a Dembowa Gora Dembowski, Dei et Apostolicae Sedis gratia episcopi Plocensis, expost nominati Vladislaviensis et Pomeraniae, et a Curia eiusdem ad ecclesias suae dioecesis, capitula, parochos et parochianos directarum, copias in se translatas et ingrossatas, cum ad notatione utilium sciendorum et informationum continens.

\section{Biblioteka Zakladu Narodowego im. Ossolińskich we Wroclawiu (Ossolineum)}

rkp 1735/II - Liber sacrorum ordinum variis ecclesiasticis personis per me, Jaco- 
bum Valerianum Tumanowicz, episcopum Camacensem, coadiutorem archiepiscopatus Leopoliensis Armenorum, collatorum aliarumque consecrationum factarum ab anno Domini 1772 [1782-1798].

$* * * * *$

\section{URODZINY (CHRZTY)}

\section{1}

Dembowski Antoni Sebastian biskup (Płock-Włoctawek) chrzest 2 II $1682^{2}$

AKapMK, KP 226, k. 4r [s. 1] (Literae metrices baptismi)

Anno Domini millesimo sexcentesimo octuagesimo secundo, die secunda Februarii [= 2 II 1682]. Ego Matthias Wilamowski, parochus ecclesiae Zembroviensis, baptisavi infantem nomine Antonium, Generosi Floriani Dembowski Evaeque, legitimorum coniugum. Lavantes Magnificus Dominus Adamus Sobolewski, iudex terrae Drohiciensis, cum Generosa Domina Constantia Krzeczkowska.

\section{2}

Geritz Józef Ambroży biskup (Warmia)

urodziny $3 \mathrm{IV} 1783$ (chrzest $5 \mathrm{IV})^{3}$

AAWO, AB H 150, s. 3 (Notitia praeliminaria)

${ }^{2}$ A. J. Nowowiejski, Płock. Monografia historyczna, Płock [1931], s. 69 nr LXVII (,ur. 1682 r.”); W. Konopczyński, Dembowski Antoni Sebastian (1682-1763), biskup kujawski, w: Polski Stownik Biograficzny [dalej: PSB], t. 5, Kraków 1936-1946, s. 83 („,urodził się w Zambrowie na Podlasiu 2 II 1682 r.”); Z. Szostkiewicz, Katalog biskupów obrzadku tacińskiego przedrozbiorowej Polski, w: Sacrum Poloniae Millenium. Rozprawy - Szkice-Materiaty historyczne, t. 1, Rzym 1954, s. 433 („,ur. 2 II 1682 r.”); Hierarchia Catholica medii et recentioris aevi [dalej: HC], t. 6-1730-1799, cur. R. Ritzler, P. Sefrin, Patavii 1958, s. 342 (,natus in loco Zambroviensi dioecesis Plocensis, baptizatus 2 Februarii 1682”); T. Żebrowski, Zarys dziejów diecezji płockiej, Płock 1976, s. 58, nr 61 („urodził się w 1682 r.”); P. Nitecki, Biskupi Kościoła w Polsce w latach 965-1999. Słownik biograficzny, Warszawa 2000, kol. 72 (,ur. 1 II 1682 r.”).

${ }^{3}$ HC, t. 7, s. 55 („,natus Seeburgi dioecesis Varmiensis 3 Aprilis 1783”); Die Bischöfe der deutschsprachigen Länder 1785/1803 bis 1945. Ein biographisches Lexikon, red. E. Gatz, Berlin 1983, s. 244 (G. Reifferscheid) (,wurde am 3 IV 1783 in Seeburg (Ermland) geboren”); S. Achremczyk, R. Marchwiński, J. Przeracki, Poczet biskupów warmińskich, Olsztyn 1994, s. 207 (,przyszedł na świat w Jezioranach, małym miasteczku warmińskim, 3 IV 1783 r.”); Stownik biograficzny kapituly warmińskiej, Olsztyn 1996, s. 68 (M. Borzyszkowski) (,ur. 3 IV 1783 r. w Jezioranach”); Nitecki, Biskupi Kościoła w Polsce, kol. 114 (,ur. 3 IV 1783 r.”). 
Ego Josephus Ambrosius [Geritz] natus anno Domini MDCCXXXIII, die $3^{\text {tia }}$ Aprilis, Seeburgi in oppido dioecesis Varmiensis, et ibidem in ecclesia archipresbyterali $5^{\text {ta }}$ eiusdem sacro baptizmatis fonte regeneratus [sum]; in eadem ecclesia sacramentum confirmationis anno 1790 recepi a Celsissimo Sacri Romani Imperii Principe Ignatio Krasicki, episcopo Varmiensi.

Hatten (Hattyński) Andrzej Stanisław biskup (Warmia)

urodziny 31 VIII $1763^{4}$ AAWO, AB H 149, k. [1a]r

Ego Andreas Stanislaus ab Hatten die 31. mensis Augusti anno 1763 in bonis Lemitten, Varmiensis dioecesis, natus, ac in parochiali ecclesia Kalksteinensi baptizatus [sum]. Confirmationis sacramentum obtinui a Celsissimo Principe Ignatio e Sacri Romani Imperii comitibus Krasicki, episcopo Varmiensi, in ecclesia archipresbyterali Brunsbergensi die 26. Novembris anno 1779.

\section{ŚWIĘCENIA}

\section{1}

Dembowski Antoni Sebastian biskup (Płock - Wtocławek) święcenia niższe 21 XII 1735 subdiakonat $8 \mathrm{IV} 1736$ diakonat 11 IV 1736 prezbiterat $15 \mathrm{IV} 1736^{5}$

${ }^{4}$ J. Obłąk, Hatten Andrzej Stanisław (1763-1841), biskup warmiński, PSB, t. 9, s. 303 („,ur. 31 VIII 1763 r. w Limitach koło Ornety”); HC, t. 7, s. 176 („natus in parochia de Kalkstein dioecesis Varmiensis 31 Augusti 1763") Die Bischöfe der deutschsprachigen Länder 1785/1803 bis 1945, s. 290 (A. Triller) (,wurde am 31 VIII 1763 auf dem väterlandischen Erbgute Lemitten bei Wormditt geboren"); S. Achremczyk, R. Marchwiński, J. Przeracki, Poczet biskupów warmińskich, s. 203 (,urodził się 31 VIII 1763 r. w Limitach koło Ornety”); Słownik biograficzny kapituły warmińskiej, s. 83 (M. Borzyszkowski) (,ur. 31 VIII 1763 r. w Lemitach koło Ornety”); Nitecki, Biskupi Kościoła w Polsce, kol. 140 (,ur. 31 VIII 1763 r.”).

${ }^{5}$ A. J. Nowowiejski, Ptock. Monografia historyczna, s. $69 \mathrm{nr}$ LXVII (,w r. 1736 został kapłanem"); Konopczyński, Dembowski Antoni Sebastian, s. 84 (brak dat święceń); Szostkiewicz, Katalog biskupów obrzq̨dku łacińskiego, s. 433 („, 1735 r. otrzymał święcenia kapłańskie”); HC, t. 6, s. 342 (,promotus ad ordines minores 21 Decembris 1735, subdiaconatus, diaconatus et presbiteratus 8, 11, 15 Aprilis 1736“); Żebrowski, Zarys dziejów diecezji płockiej, s. 58, nr 61 („święcenia kapłańskie przyjął dopiero w 1735 r.”); Nitecki, Biskupi Kościoła w Polsce, kol. 72 (,święcenia przyjął w r. 1735”). Por. „Gazety Polskie”, 1735, nr 92, s. [2]; 1735, nr 94, s. [2]; K. R. Prokop, Wiadomości do biografii biskupów oraz opatów i ksień z ziem Rzeczypospolitej Obojga Narodów 
AKapMK, KP 226, k. 4r-v [s. 1-2] (Minores ordines - dokument $z$ daty: Warszawa, 11 I 1736), k. 4v-5r [s. 2-3] (Maiores ordines - dokument z daty: [Warszawa], 15 IV 1736)

Stanislaus Josephus de Bezdan Hosius, Dei et Apostolicae Sedis gratia episcopus Posnaniensis, abbas perpetuus commendatarius Cervenensis. Universis et singulis [...] fidem indubiam facimus et testamur, qualiter nos, die vigesima prima mensis Decembris anno Domini millesimo septingentesimo trigesimo quinto, ipso die Sancti Thomae Apostoli [=21 XII 1735], in capella Reverendorum Patrum Societatis Jesu Varsaviensi, Illustrissimum Antonium Sebastianum Dembowski, referendarium Regni, dioecesis nostrae [...], ad primam tonsuram et quatuor minores ordines $[\ldots]$ rite promovimus et ordinamus.

Stanislaus Josephus de Bezdan Hosius, Dei et Apostolicae Sedis gratia episcopus Posnaniensis, abbas perpetuus commendatarius Cervenensis. Universis et singulis [...] fidem indubiam facimus et testamur, qualiter nos anno Domini 1736, in capella privata Patrum Societatis Jesu [Varsaviensi], intra Missarum solennia, particulares ordinationes habentes, Illustrissimum Antonium Sebastianum Dembowski, referendarium Regni Poloniae, dioecesis nostrae [...], die quidem octava Aprilis, Dominica in Albis incidente [ $=8$ IV 1736], ad ordinem subdiaconatus, in titulum mensae episcopalis, die vero undecima eiusdem mensis [= 11 IV 1736] ad ordinem diaconatus, et die decima quinta etiam eiusdem mensis [= 15 IV 1736] ad ordinem praesbyteratus, praevia dispensatione in interstitiis, et extra tempora, [...] rite promovimus et ordinavimus.

Geritz Józef Ambroży biskup (Warmia)

święcenia niższe 12 VI 1802 subdiakonat 1 III 1806

diakonat 9 III 1806

prezbiterat $5 \mathrm{IV} 1806^{6}$

AAWO, AB H 150, s. 3 (Notitia praeliminaria)

[Ego Josephus Ambrosius Geritz] statum clericalem amplectens anno 1802 ab Illustrissimo Domino Andrea Stanislao ab Hatten, episcopo Dianensi, suffraganeo, cantoreo et canonico Varmiensi, Sabbato IV Temporum Pentecostes, quae fuit

z osiemnastowiecznej prasy warszawskiej doby saskiej i stanistawowskiej (1729-1795), „Archiwa, Biblioteki i Muzea Kościelne”, 86 (2006) s. 298, przyp. 25.

${ }^{6} \mathrm{HC}$, t. 7, s. 55 (,promotus ad ordines minores 12 Iunii 1802, subdiaconatus et diaconatus 1 , 9 Martii 1806, presbiteratus 5 Aprilis 1806”); Die Bischöfe der deutschsprachigen Länder 1785/1803 bis 1945, s. 244 (,am 5 IV 1806 wurde er in Frauenburg zum Priester geweiht”); Achremczyk, Marchwiński, Przeracki, Poczet biskupów warmińskich, s. 207 (,5 IV 1806 r. otrzymał święcenia kapłańskie w Braniewie”); Stownik biograficzny kapituły warmińskiej, s. 68 („5 IV 1806 r. przyjął święcenia kapłańskie we Fromborku”); Nitecki, Biskupi Kościoła w Polsce, kol. 114 (,święcenia w r. 1806"). 
dies $12^{\underline{m a}}$ mensis Junii, in Capella Sanctissimi Salvatoris ad ecclesiam cathedralem Varmiensem tonsuram clericalem recepi et statim ad quatuor minores ordines fui promotus.

Anno Domini 1806, Sabbato IV Temporum Quadragesimae, quae fuit dies $1^{\text {ma }}$ mensis Martii, ab Illustrissimo Domino Andrea Stanislao ab Hatten, eodem, qui retro, in Capella Sanctissimi Salvatoris ad ecclesiam cathedralem Varmiensem ad sacrum subdiaconatus ordinem fui promotus, provisus ad vicariam ecclesiae cathedralis Varmiensis.

Anno eodem, Dominica III Quadragesimae, quae fuit dies $9^{\text {na }}$ mensis Martii, ab eodem Illustrissimo Domino in eadem Capella, praevia dispensatione super interstitiis et temporibus, ad sacrum diaconatus [ordinem] fui promotus.

Anno eodem, Sabbato Sancto, quae fuit dies $5^{\text {ta }}$ mensis Aprilis, ab eodem Illustrissimo Domino, in eadem Capella, praevia dispensatione super interstitiis et aetate 11 mensium et 28 dierum, ad sacrum presbyteratus ordinem fui promotus.

Hatten (Hattyński) Andrzej Stanisław biskup (Warmia)

święcenia niższe 1 I 1781 subdiakonat 18 XII 1784 diakonat 4 IX 1785 prezbiterat 1 IV $1786^{7}$

AAWO, AB H 149, k. [1a]r

[Ego Andreas Stanislaus ab Hatten] statum clericalem amplectens die 1. Januarii anno $1781 \mathrm{ab}$ Illustrissimo Carolo 1 [iber] b[arone] de Zehmen, suffraganeo Varmiensi ac Lettensi episcopo, Fraumburgi in Capella Sanctissimi Salvatoris ecclesiae cathedralis Varmiensis, ad primam tonsuram ac quatuor minores ordines fui promotus.

Anno 1784, die 18. Decembris, Sabbatho Quatuor Temporum, Romae, in Sacrosancta Lateranensi Basilica, ab Illustrissimo Josepho Maria Contesini, Athenarum archiepiscopo, ad missionis titulum, in Collegio Germanico degens, in subdiaconum fui ordinatus.

${ }^{7}$ Obłąk, Hatten Andrzej Stanisław, s. 303 („1 IV 1786 r. otrzymał w Rzymie święcenia kapłańskie”); HC, t. 7, s. 176 (,promotus ad ordinem presbyteratus 1 Aprilis 1786”); Die Bischöfe der deutschsprachigen Länder 1785/1803 bis 1945, s. 290 (,am 1 IV 1786 zum Priester geweiht”); Achremczyk, Marchwiński, Przeracki, Poczet biskupów warmińskich, s. 203-204 („1 I 1781 r. otrzymał niższe święcenia kapłańskie [sic!]; 1 IV 1786 r. w Rzymie otrzymał wyższe święcenia kapłańskie i stopień doktora teologii”); Stownik biograficzny kapituly warmińskiej, s. 83 („1 IV 1786 r. przyjął święcenia kapłańskie w Rzymie”); Nitecki, Biskupi Kościoła w Polsce, kol. 140 (,święcenia przyjął w Rzymie w r. 1786”). 
Anno 1785, die $4^{\text {ta }}$ Septembris, Romae, in coenobio Ordinis Sancti Benedicti ad Sanctum Calixtum dicto, ab Illustrissimo Petro Aloysio Galletti, episcopo Cyrenensi, in ipsius capella privata in diaconum fui ordinatus.

Anno 1786, Sabbatho Sitientes [ante primam Passionis Dominicam], quae fuit dies 1. Aprilis, Romae, in Sacrosancta Lateranensi Basilica, ab Illustrissimo Nicolao Buschi, archiepiscopo Ephesino, ad presbyteratus ordinem fui promotus.

\section{4}

Hohenzollern Jan Karol biskup (Chetmża - Warmia) subdiakonat 24 V 1777

diakonat 1 VI 1777

prezbiterat 29 VI $1777^{8}$

ADP, C 54a [V 23], s. 127

[Anno Domini] 1777. Ad sacrum ordinem subdiaconatus Sabbatho $4^{\text {tuor }}$ temporum ante festum Sanctissimae Trinitatis, quae fuit dies 24. Maii, in ecclesia archipresbyterali Culmensi, intra missarum solemnia, ordinatus est Illustrissimus [et] Reverendissimus Dominus Carolus de Hohenzollern, Sacri Romani Imperii comes, ad titulum canonicatus Vratislaviensis cum dimissoriis.

Ad sacrum ordinem diaconatus, eodem anno, Dominica infra octavam Corporis Christi, $2^{\mathrm{da}}$ post Pentecosten, quae fuit dies $1^{\text {ma }}$ Junii, in ecclesia parochiali Starogrodensi ordinatus est Illustrissimus et Reverendissimus Dominus Carolus comes de Hohenzollern, praevia dispensatione ab interstitiis et temporibus.

Ad presbyteratum, eodem anno, festo sanctorum Apostolorum Petri et Pauli incidente in Dominicam $6 \frac{\text { tam }}{}$ post Pentecosten, quae fuit dies 29. Junii, ordinatus [est] in ecclesia archipresbyterali Lubaviensi, inter missarum solemnia, idem Illustrissimus [et] Reverendissimus Dominus Carolus comes de Hohenzollern, cum dispenstatione ab interstitiis et temporibus.

${ }^{8}$ Diecezja chetmińska. Zarys historyczno-statystyczny, Pelplin 1928, s. 48, nr 48 („,kapłan 1777 r.”); Szostkiewicz, Katalog biskupów obrzqdku łacińskiego, s. 467 („wyświęcony na księdza w 1777 r.”); HC, t. 6, s. 189 (,subdiaconatus 24 Maii 1777, diaconatus et presbyteratus 1, 29 Iunii 1777”); Die Bischöfe des Heiligen Römischen Reiches 1648 bis 1803. Ein biographisches Lexikon, red. E. Gatz, Berlin 1990, s. 190 (A. Triller) („1777 wurde er Priester und Domkapitular in Breslau”); Achremczyk, Marchwiński, Przeracki, Poczet biskupów warmińskich, s. 192 („,w 1776 roku otrzymał święcenia kapłańskie i kanonię wrocławską"); Słownik biograficzny kapituły warmińskiej, s. 93 (M. Borzyszkowski) („święcenia kapłańskie przyjął w roku 1776”); J. Pater, Wrocławska kapituła katedralna w XVIII wieku. Ustrój - skład osobowy - działalność, Wrocław 1998, s. 194 („, 1776 r. przyjął święcenia kapłańskie”); Nitecki, Biskupi Kościoła w Polsce, kol. 150 („,święcenia w r. 1777”); Z. Iwicki, Nekropolia oliwska, Gdańsk 2004, s. 157 („święcenia kapłańskie przyjął 29 VI 1777 r. w Lubawie"). 
Potoczki Jan Antoni biskup (Przemyśl)

subdiakonat 26 VI 1786 diakonat 9 VII 1786

prezbiterat 12 VIII $1786^{9}$

Ossolineum, rkp 1735/II, k. 6v

Anno Domini 1786, die 26. Junii, in Festo SS. Principum Apostolorum Petri et Pauli, infra missarum solemnia, [Illustrrissimus ac Reverendissimus Dominus Jacobus Valerianus Tumanowicz, archiepiscopus Leopoliensis ritus Armeni] contulit ordinem subdiaconatus Admodum Reverendi Joanni Potoczki, alumno Seminarii Generalis Leopoliensis, natione Hungara, ex urbe Elisabethiopolitana.

Anno Domini 1786, die 9. Julii, quae fuit Dominica Quinta post Pentecosten, infra missarum solemnia, in ipsa Octava Festi S. Gregorii Patriarchae nostri, [idem Illustrissimus ac Reverendissimus Dominus Jacobus Valerianus Tumanowicz] contulit ordinem diaconatus Reverendo Joanni Potoczki, alumno Seminarii Generalis Leopoliensis, natione Hungaro, ex urbe Elisabethopolitana oriundo.

Anno Domini 1786, die 12. Augusti, quae fuit Dominica decima post Pentecosten, [...] infra missarum solemnia [idem Illustrissimus ac Reverendissimus Dominus Jacobus Valerianus Tumanowicz] contulit ordinem praesbyteratus Reverendo Joanne Potoczki, alumno Seminarii Generalis Leopoliensis, natione Hungaro ex urbe Elisabethana oriundo et sub titulo vicarii ecclesiae Elisabethanae ritus nostri provisi, ad sacrum ordinem praesbyteratus promovit et consecravit.

Zachariaszewicz Franciszek Ksawery biskup (Tarnów - Przemyśl) subdiakonat 30 V 1795 diakonat 29 VI 1795 prezbiterat 26 VII $1795^{10}$

${ }^{9}$ S. Barącz, Żywoty sławnych Ormian w Polsce, Lwów 1856, s. 280 (,został kapłanem w r. 1786”); W. Sarna, Biskupi przemyscy obrzqdu tacińskiego, t. 2, Przemyśl 1910, s. 522 („święcenia kapłańskie otrzymał z rąk Jakuba Tumanowicza, arcybiskupa ormiańskiego"); HC, t. 7, s. 314 (,subdiaconatus 29 Iunii 1786, diaconatus 9 Iulii 1786, presbyteratus 12 Augusti 1786”); T. Śliwa, Potoczki (Potocki) Jan Antoni (1759-1832), rektor Uniwersytetu Lwowskiego, biskup przemyski obrzqdku łacińskiego, PSB, t. 28, s. 238 („,dn. 12 VII 1786 r. otrzymał święcenia kapłańskie w obrządku ormiańskim”); Nitecki, Biskupi Kościoła w Polsce, kol. 358 („święcenia w r. 1786”); T. Zaleski, Stownik biograficzny duchownych ormiańskokatolickich oraz duchownych rzymskokatolickich pochodzenia ormiańskiego w Polsce w latach 1750-2000, Kraków 2001, s. 87 nr 187 (brak dat święceń).

${ }^{10}$ Barącz, Żywoty sławnych Ormian, s. 387 (,w r. 1795 kapłańskie wziął święcenia”); W. Sarna, Biskupi przemyscy obrzqdu łacińskiego, t. 2, s. 533 (,w r. 1795 otrzymał święcenia kapłańskie”); HC, t. 7, s. 359 (,subdiaconatus 26 Iulii 1795, diaconatus et presbyteratus 2, 9 Augusti 1795”); B. Kumor, Diecezja tarnowska. Dzieje ustroju i organizacji 1786-1985, Kraków 1985, s. 262 („tonsurę 
Ossolineum, rkp 1735/II, k. 10r

Anno Domini 1795, die 30. Maii, quae fuit Sabbatho Quatuor Temporum, in vigilia SS. Trinitatis, ordinatus [est] infra missarum solemnia et ad subdiaconatum promotus Franciscus Xaverius Zachariaszewicz, origine Stanislavoviensi, alumnus Seminarii Caesarei Leopoliensis.

Anno Domini 1795, die 29. Junii, quae fuit Lunae Festi SS. Principum Apostolorum Petri et Pauli, [...] infra missarum solemnia ordinatus [est] in diaconum Franciscus Xaverius Zachariaszewicz, origine Stanislavoviensi, alumnus Seminarii Caesarei [Leopoliensis].

Anno Domini 1795, die 26. Julii, quae fuit Dominica nona post Pentecosten et Festum S. Annae, infra missarum solemnia ordinatus est in praesbyterum [...] Reverendus Franciscus Xaverius Zachariaszewicz, origine Stanislavoviensi, alumnus Seminarii Caesarei Leopoliensis.

\section{BENEDYKCJE}

\section{1}

[Dambska Lidwina] ksieni (Chetmno)

benedykcja 17 XI $1741^{11}$

ADP, AKKCh A 16, s. 109 (gdzie poniżej dopiska: Praeterea benedixit abbatissam Thoruniensem, item abbatissam Graudentinensem)

Illustrissimus, Excellentissimus et Reverendissimus Dominus Matthias Alexander Sołtyk, episcopus Margaritensis, suffraganeus Culmensis, [] anno Domini 1741, die 17. Novembris, benedixit abbatissam Culmensem.

\footnotetext{
i święcenia niższe otrzymał 19 VII 1795 r., subdiakonat - 26 VII tr., diakonat - 2 VIII tr., a kapłaństwo - 9 VIII 1795 r. w obrządku ormiańskim z rąk arcybiskupa Jakuba Tumanowicza”); Nitecki, Biskupi Kościoła w Polsce, kol. 503 (,święcenia przyjął w obrządku ormiańskim w r. 1795”); Zaleski, Stownik biograficzny duchownych ormiańskokatolickich oraz duchownych rzymskokatolickich pochodzenia ormiańskiego, s. 109 nr 243 (,wyświęcony w 1795 r. przez arcybiskupa Jakuba Tumanowicza").

${ }^{11}$ M. Borkowska, Stownik polskich ksień benedyktyńskich (Siostry zakonne w Polsce. Stownik biograficzny, t. 2), Niepokalanów 1996, s. 27 („ksieni benedytynek chełmińskich 1741-1761”); M. Borkowska, Leksykon zakonnic polskich epoki przedrozbiorowej, t. 1: Polska Zachodnia i Pólnocna, Warszawa 2004, s. 303 (,w r. 1741 obrana ksienią chełmińską. Zmarła 16 IV 1761 r. po długiej chorobie").
} 
Kirkorowiczówna (Teodorowiczówna) Ksaweria Gertruda ksieni (Lwów)
benedykcja I V $1791^{12}$

Ossolineum, rkp 1735/II, k. 8v

Anno Domini 1791, die Dominica 1. Maii, [Illustrrissimus ac Reverendissimus Dominus Jacobus Valerianus Tumanowicz, archiepiscopus Leopoliensis ritus Armeni] benedixit in abbatissimam [sic] monasterii monialium nostrarum sub regula s. Benedicti fundatarum, Venerabilem Xaveriam Kirkorowiczowna, virginem, Stanislaopolitanam, plus quam triginta annis monastiam vitam observantem.

\section{3}

Knutowna Dorota ksieni (Grudziqdz)

benedykcja $28 \times 1634^{13}$

ADP, C 9 - [Acta curiae 1625-1635], k. 258v (tamże, k. 258v-259r: Iuramentum abbatissae Graudentinensis 1634)

Die 28. Octobris anno Domini 1634 [facta est] consecratio abbatissae Graudentinensis Dorotheae Knutowna.

${ }^{12}$ Borkowska, Stownik polskich ksień benedyktyńskich, s. 168 (,gdy w r. 1789 wybrano ją następczynią ksieni R. Matiaszewiczówny, choć władze austriackie nie robiły trudności z zatwierdzeniem, długo zwlekała z przyjęciem urzedu i wreszcie zdecydowała się na to dopiero w r. 1791, kiedy też odbyła się benedykcja”); Borkowska, Leksykon zakonnic polskich epoki przedrozbiorowej, t. 3, s. 252 („Obrana ksienią w r. 1789 i zatwierdzona przez gubernium, nie chciała przyjąć urzędu i benedykcję otrzymała dopiero w r. 1791. Zmarła 9 V 1796 r.”). Por. Barącz, Żywoty sławnych Ormian, s. 472-473 („Po śmierci Najprzewielebniejszej ksieni Magdaleny Rypsymy Matyaszewiczówny, dnia 27 VI 1789 r. [...] ksienią klasztoru [lwowskiego] obrana została Xawera Teodorowiczówna ze Stanisławowa, dnia 21 VIII potwierdzoną przez Najjaśniejszego Pana. Lecz w żaden sposób nie chciała przyjąć tego urzędu. Przez dwa lata prawie zwlekała konsekrację [i] dopiero za prośbą i radą dobrych przyjaciół dnia 1 V 1791 r. przystąpiła do konsekracji”).

${ }^{13}$ Borkowska, Stownik polskich ksień benedyktyńskich, s. 69 („ksieni benedyktynek w Grudziądzu 1631-1641. [...] Gdy jej siostra założyła klasztor w Grudziądzu w r. 1631, została tam posłana jako starsza, potem pierwsza ksieni. [...] W r. 1634 liczba sióstr pozwoliła już na oficjalną elekcję ksieni”); Borkowska, Leksykon zakonnic polskich epoki przedrozbiorowej, t. 1, s. 291 („w r. 1631 posłana jako pierwsza starsza na fundację do Grudziądza. Zmarła 10 III 1641 r.”).

${ }^{14}$ Borkowska, Stownik polskich ksień benedyktyńskich, s. 119-120 (,ksieni benedyktynek w Toruniu 1631-1651. Obrana następczynią Z. Dulskiej, podjęła jej dawny sprzeciw wobec chełmińskiego wydania reguły. Może dlatego zwlekała 3 lata z przyjęciem benedykcji, podczas której musiała 
ADP, C 9 - [Acta curiae 1625-1635], k. 247r (tamże, k. 247r-v: Iuramentum abbatisae Toruniensis 1634, 14. Octobris)

Die 14. Octobris anno Domini 1634 consecrationem abbatissae conventus [Thorunensis] Elisabethae Piwnicka peregit.

\section{5}

Wielhorska Anna ksieni (Sokal)

benedykcja $[1718 ?]^{15}$

AAWO, AK Ab 28 - [Listy różne 1712-1721], k. 39v-40r. (dokument biskupa chetmskiego Krzysztofa Jana Szembeka z daty: Skierbieszów, 7 X 1718 r.)

Religiosa ac Deodicata Virgo Anna Wielhurska, abbatissa monalium Socaliensium Ordinis et Regulae Sanctae Matris Brigittae, dioecesis nostrae Chełmensis, per nos benedicta [est].

\section{ZGONY}

Bajer Andrzej Ignacy biskup (Chetmża)

$+31 I 1785^{16}$

ADP, AKKCh A 14 - [Acta capituli Culmensis 1773-1792], k. 126r (Obitus Illustrissimi, Excellentissimi ac Reverendissimi Domini Andreae Ignatii de Broniewice Baier, episcopi Culmensis ac Mariaeburgensis in Pomesania)

by przysięgać na zatwierdzony przez Stolicę Apostolską (a więc chełmiński) tekst. W paździeniku 1634 r. biskup J. Zadzik wymógł na niej taką przysięgę i udzielił benedykcji”); taż, Leksykon zakonnic polskich epoki przedrozbiorowej, t. 1, s. 294 („Obrana ksienią w marcu 1631 r. Z początku niechętna regule chełmińskiej, przyjmuje ją ostatecznie w r. 1634 i otrzymuje benedykcję").

${ }^{15}$ Borkowska, Leksykon zakonnic polskich epoki przedrozbiorowej, t. 3, s. 325 (brak w nocie biograficznej jakichkolwiek dat, podobnie jak i informacji o benedykcji). Zob. także: J. Swastek, Święta Brygida Szwedzka i Zakon Najświętszego Zbawiciela-ze szczególnym uwzglęnieniem klasztorów na ziemiach polskich, cz. 2, Lublin 1986, s. 341.

${ }^{16}$ Diecezja chetmińska, s. 48 nr 47 („umarł w Chełmży 31 I 1785 r.”); Szostkiewicz, Katalog biskupów obrzqdku łacińskiego, s. 409 („,zmarł 31 I 1785 r.”); HC, t. 6, s. 189 („,obiit 31 Ianuarii 1785"); K. Dola, Katalog arcybiskupów i biskupów rezydencjalnych metropolii i diecezji polskich obrzqdku rzymskokatolickiego do czasów współczesnych, w: Historia Kościoła w Polsce, red. B. Kumor, Z. Obertyński, t. 2: 1764-1945, cz. 2: 1918-1945, Poznań-Warszawa 1979, s. 260, nr 49 (,zm. 31 I 1785 r.”); Die Bischöfe des Heiligen Römischen Reiches 1648 bis 1803, s. 22 (H. J. Karp) (,starb am 31 I 1785”); Stownik biograficzny Pomorza Nadwiślańskiego [dalej: SBPN], t. 1, Gdańsk 1992, s. 55 (J. Dygdała) (,zm. 31 I 1785 r. w Chełmży i tam też został pochowany”); Słownik biograficzny kapituły warmińskiej, s. 14 (A. Kopiczko) (,zm. 31 I 1785 r. w Chełmży i został pochowany w tamtejszej katedrze”); Nitecki, Biskupi Kościoła w Polsce, kol. 15 (,zm. 31 I 1785 r.”). 
Congregatum est [1 II 1785] praesens capitulum orbatum magno in rerum turbine et ancipiti in certamine derelictum ab integerrimo et vigilantissimo pastore Andreae Ignatis, qui post exanclatos circa 25 annorum dioecesis gubernacula labores, multisque vitae actibus summa cum laude peractis [...], adveniente Divinae vocationis hora, sumptis pridie obitus sui devotissima mente salutaribus sacramentis intrepide cidio spiritum die 31. mensis Januarii, circa horam tertiam post meridiem, reddidit Creatori.

ADP, AKKCh A 55 - [Anniversaria et fundationes XVII w. - 1809 r.], k. $6 r$

Andreas Ignatius de Broniewice Bajer, episcopus Culmensis, mortuus [est] anno 1785 , die $31^{\text {ma }}$ Januarii.

Bokum (de Alten Bokum) Jan Kazimierz biskup (Przemyśl - Chetmża)

+30 VI $1721^{17}$

ADP, AKKCh 48, s. 255-256 (Obitus Excellentissimi, Illustrissimi, Reverendissimi Domini Joannis Casimiri de Alten Bokum, episcopi Culmensis et Pomesaniae, procancellarii Regni)

Tristis nuntius venit Lubavia cum fatali relatione subitaneae mortis Illustrissimi, Reverendissimi Domini Joannis Casimiri de Alten Bokum, episcopi Culmensis et Pomesaniae, abbatis Czervenensis, procancellarii Regni, qui intra septimam et octavam horam ante occasum solis, sanus mente et corpore existens recreationis causa profectus ad praedium Byszfałd, ubi de repente cordis dolore oppressus langvescere coepit et in illa debilitate vix mediam agens horam, cum fatis vitam commutavit die ultima Junii [= 30 VI 1721]. Cuius anima sit in benedictione.

${ }^{17}$ Sarna, Biskupi przemyscy obrzadu łacińskiego, t. 2, s. 394 („umarł nagle w r. 1722”); Diecezja chetmińska, s. $46 \mathrm{nr} 41$ (,,30 VI 1721 r. niespodziewanie umarł w Byszwałdzie pod Lubawą”); J. Kwolek, Bokum Jan Kazimierz de Alten (1666-1721), biskup przemyski, potem chetmiński, podkanclerzy koronny, PSB, t. 2, Kraków 1936, s. 247 (,,zmarł nagle 30 VI 1721 r. w Bryszwałdzie [sic] pod Lubawą”); H. Folwarski, Poczet opatów klasztoru kanoników regularnych w Czerwińsku, „Nasza Przeszłość”, 6 (1957) s. 46 (,zmarł 30 VII [sic!] 1721 r.”); HC, t. 5, s. 178 („,obiit 30 Iunii 1721”); Szostkiewicz, Katalog biskupów obrzqdku łacińskiego, s. 417 (,umarł nagle 30 VI 1721 r.”); Dola, Katalog arcybiskupów i biskupów, s. $260 \mathrm{nr} 43$ (,zm. 30 VI 1721 r.”); Die Bischöfe des Heiligen Römischen Reiches 1648 bis 1803, s. 36-37 (H. J. Karp) (,starb am 30 VI 1721 in Bischwalde bei Löbau"); Urzędnicy centralni i nadworni Polski XIV-XVIII wieku. Spisy, (Urzędnicy dawnej Rzeczypospolitej XII-XVIII wieku. Spisy, t. 10), Kórnik 1992, s. 113 nr 677 („† 30 VI 1721”); Nitecki, Biskupi Kościoła w Polsce, kol. 37 (,zm. 30 VI 1721 r.”). 
Bystram Maciej biskup (Argos)

+13 VIII $1677^{18}$

ADP, AKKCh A 65 - [Acta capituli Culmensis 1661-1690], s. 265-266 (Obitus Perillustris et Reverendissimi Domini Bystram)

Perillustris et Reverendissimus Dominus Matthias Bystram, episcopus Argivensis, suffraganeus, archidiaconus, officialis generalis Culmensis, parochus Thorunensis, grandis aevi spacio pro dioecesi hac annis quadraginta duobus ab Illustrissimo et Reverendissimo Domino Jacobo Zadzik, episcopo Culmensi et Pomesaniae, etc. etc., creatus canonicus Culmensis, laborans, meritissimus in Ecclesia Dei praesul, aliquot septimanis infirmus, [...] bene dispositus, omnibus ad vitam immortalem munitus Sacramentis, vias mortalitatis ingressus die decima tertia mensis Augusti anni currentis [= 13 VIII 1677], circa horam nonam vespertinam. Eiusdem cineres venerandi debitae mandati sepulturae die $6^{\text {ta }}$ Septembris anni currentis [= 6 IX 1677]. Cuius anima sit in benedictionibus.

\section{4}

Czapski Tomasz Franciszek biskup (Chetmża)

+23 IV $1733^{19}$

ADP, AKKCh A 49, k. 134r (Obitus Illustrissimi et Reverendissimi Thomae Francisci Czapski, episcopi Culmensis et Pomesaniae)

${ }^{18}$ R. Frydrychowicz, Die Culmer Weihbischöfe. Ein Beitrag zur Diözesangeschichte, Danzig 1905, s. 13 („starb am 5 VIII 1677”); A. Mańkowski, Prałaci i kanonicy katedralni chetmińscy od założenia kapituly do naszych czasów, Torun 1928, s. 17 (,umarł 5 VIII 1677 r.”); por. tamże przyp. 8 (,nagrobek jego podaje jako datę śmierci 13 VIII 1676 r.”); HC, t. 4, s. 94 (brak daty śmierci); A. Mańkowski, Bystram Maciej († 1677), sufragan chetmiński, PSB, t. 3, s. 170 (,umarł mając lat 75 dnia 5 VIII 1677 (na nagrobku data śmierci 13 VIII 1676)"); Szostkiewicz, Katalog biskupów obrzqdku łacińskiego, s. 422 (brak daty zgonu); Die Bischöfe des Heiligen Römischen Reiches 1648 bis 1803, s. 57 (H.J. Karp) (,starb am 5 VIII 1677 im Alter von 75 Jahren”); SBPN, t. 1, s. 187 (S. Achremczyk) (,zm. 5 VIII 1677 r.”); Nitecki, Biskupi Kościoła w Polsce, kol. 46 („,zm. 5 VIII 1677 r.").

${ }^{19}$ R. Frydrychowicz, Geschichte der Cistercienserabtei Pelplin und ihre Bau-und Kunstdenkmäler, Düsseldorf 1905, s. 112 (,starb am 23 IV 1733 im 55. Lebensjahr”); Diecezja chetmińska, s. 46-47 nr 43 (,po powrocie z sejmiku malborskiego zaniemógł i umarł w Starogrodzie [roku 1733], pochowany w Chełmży”); A. Mańkowski, Czapski Tomasz Franciszek († 1733), biskup chetmiński, PSB, t. 4, s. 194 (,zaniemógł w Starogardzie i tutaj zmarł 23 IV 1733 r.”); HC, t. 5, s. 178 („obiit mense Aprili 1733“); Szostkiewicz, Katalog biskupów obrzq̨dku łacińskiego, s. 428 (,zmarł w kwietniu 1733 r.”); Dola, Katalog arcybiskupów i biskupów, s. 260 nr 45 (,,zm. 23 IV 1733 r.”); Die Bischöfe des Heiligen Römischen Reiches 1648 bis 1803, s. 72 (H.J. Karp) („starb am 23 IV 1733 in der bischöflichen Residenz Althausen bei Kulm”); SBPN, t. 1, s. 260 (S. Achremczyk) („po powrocie z sejmiku zmarł 23 IV 1733 r. w Starogardzie"); Nitecki, Biskupi Kościoła w Polsce, kol. 62 (,zm. 23 IV 1733 r.”). 
Capitulum extraordinarium die 23. Aprilis [1733] celebratum, post tristem nuntium de fatis Illustrissimi Episcopi [Thomae Francisci Czapski], praesulis sui dignissimi, cum moerore accessit ad perlegendas literas a Perillustri Domino Leski, secretario eiusdem Illustrissimi ad capitulum consignatas.

Ferber Maurycy biskup (Warmia)

+1 VII $1537^{20}$

AAWO, $A B E b 81$, k. $2 r$

Anno 1537, prima Dominica mensis Julii, mane, in tactu horae 3., obiit Reverendissimus Mauritius Ferber, episcopus Varm[iensis], in arce Heilsbergensi.

\section{6}

\section{Grabowski Adam Stanisław biskup (Nilopolis - Chetmża - Włoctawek - Warmia) +15 XII $1766^{21}$}

${ }^{20}$ HC, t. 3, s. 327 (brak daty śmierci); T. Glemma, Ferber Maurycy († 1537), biskup warmiński, PSB, t. 6, s. 419 („,zmarł 1 VII 1537 r. i został pochowany w katedrze fromborskiej”); Szostkiewicz, Katalog biskupów obrzqdku łacińskiego, s. 445 (,zmarł 1 VII 1537 r.”); Dola, Katalog arcybiskupów i biskupów, s. 295 nr 19 („,zm. 1 VII 1537 r.”); SBPN, t. 1, s. 416 (W. Szczuczko) („,zm. 1 VII 1537 r. w Lidzbarku Warmińskim i pochowany został w katedrze we Fromborku"); Achremczyk, Marchwiński, Przeracki, Poczet biskupów warmińskich, s. 91-93 (brak daty dziennej śmierci!); Die Bischöfe des Heiligen Römischen Reiches 1448 bis 1648. Ein biographisches Lexikon, red. E. Gatz, Berlin 1996, s. 180 (H. J. Karp) („starb am 1 VII 1537 in seiner Residenz in Heilsberg”); Stownik biograficzny kapituly warmińskiej, s. 60 (T. Borawska) (,zm. 1 VII 1537 r. w Lidzbarku Warmińskim i pochowany został w katedrze fromborskiej”); Nitecki, Biskupi Kościoła w Polsce, kol. 97 (,zm. 1 VII 1537 r.”). Por. edycję źródłową w „Roczniku Dobromiejskim”, 1 (2007) s. 60-61 nr XVIII; także: J. Leo, Dzieje Prus, przeł. i wyd. J. Wojtkowski, Olsztyn 2008, s. 437; M. Oesterrreich, T. Treter, M. Treter, Kronika lidzbarska, wyd. C. P. Woelky, Olsztyn 2008, s. 79.

${ }^{21}$ Diecezja chetmińska, s. 47, nr 44 (,,umarł 15 XII 1766 r., pochowany we Fromborku”); Szostkiewicz, Katalog biskupów obrzadku łacińskiego, s. 460 („,zmarł 15 XII 1766 r.”); HC, t. 6, s. 432 („obiit 15 Decembris 1766”); S. Librowski, Grabowski Adam Stanisław (1698-1766), kolejno biskup chetmiński, włocławski $i$ warmiński, PSB, t. 8, s. 479 (,umarł w pałacu heilsberskim 15 XII 1766 r.”); J. Nowacki, Dzieje archidiecezji poznańskiej, t. 2: Archidiecezja poznańska w granicach historycznych i jej ustrój, Poznań 1964, s. 189, nr 31 (,zm. 15 XII 1766”); Dola, Katalog arcybiskupów i biskupów, s. 296 nr 37 (,zm. 15 XII 1766 r.”); Wybitni Pomorzanie XVIII wieku. Szkice biograficzne, Wrocław 1983, s. 53 (S. Achremczyk) (,zmarł po dłuższej chorobie 13 XII 1766 r. w Lidzbarku Warmińskim”); Die Bischöfe des Heiligen Römischen Reiches 1648 bis 1803, s. 158 (A. Triller) („starb am 15 XII 1766”); Achremczyk, Marchwiński, Przeracki, Poczet biskupów warmińskich, s. 177-182 (brak daty dziennej śmierci!); SBPN, t. 2, s. 95 (J. Dygdała) (,zm. 15 XII 1766 r. w Lidzbarku Warmińskim”); Nitecki, Biskupi Kościoła w Polsce, kol. 130 (,zm. 15 XII 1766 r.”). Por. J. W. Heide, Archiwum dawne i nowe lidzbarskiego kościoła archiprezbiteralnego, wyd. C. P. Woelky, Olsztyn 2006, s. 75-76, 129. Nadto: J. Obłąk, Katedra we Fromborku, Olsztyn 1980, 
AAWO, AB H 37a, s. 132 (to samo na s. 237); zob. również: AAWO, AB Ea 16c/1 i 16c/2-Deductio corporis Celsissimi, Reverendissimi principis episcopi Adami Stanislai [Grabowski]

Anno 1766, die 15 ta mensis Decembris, Dominus Adam Stanislaus Grabowski, princeps episcopus Varmiensis, facta pridie confessione sacramentali et sacro viatico provisus, media ad horam quintam vespertinam, apoplexiae tactus, in praesentia unius servi repente ex hac temporali in aeternum migravit vitam, aetatis suae 68 annorum et semiquatuor mensium [...]. Anno Domini 1767 $\stackrel{\text { mo }}{\text {, die } 6^{\text {ta }}}$ mensis Februarii, hora tertia postmeridiana, corpus exanime defuncti principis episcopi ex capella arcis, ubi a die obitus tamdiu substitit, processionaliter [...] ad ecclesiam parochialem deductum fuit.

AAWO, AK Acta Cap. 19 - Acta Reverendissimi Capituli Varmiensis ab anno 1761 ad annum 1771 inclusive, s. 422

Die 15 ta Decembris [1766] obiit in Domino Heilsbergae in arce Celsissimus et Reverendissimus princeps Adam Stanislaus a Grabow Grabowski, episcopus Varmiensis et Sambiensis, terrarum Prusiae praeses.

\section{7}

Grossman Franciszek biskup (Amyzon)

$+5 V 1852^{22}$

AAWO, AB H 150, s. 23

[Franciscus Grossman, episcopus sufraganeus Varmiensis], obiit Frauenburgio die 5 ta Maii 1852.

b.p. (fot. Ptyta nagrobna biskupa Adama Stanisława Grabowskiego przed oltarzem Najświętszego Sakramentu).

${ }^{22}$ HC, t. 7, s. 72 („obiit 5 Maii 1852“); Die Bischöfe der deutschsprachigen Länder 1785/1803 bis 1945, s. 263 (B. Poschmann) (,† 5 V 1852 in Frauenburg”); Stownik biograficzny kapituly warmińskiej, s. 77 (M. Borzyszkowski) („zm. 5 V 1852 r.”); Nitecki, Biskupi Kościoła w Polsce, kol. 133 (,,zm. 5 V 1852 r.”).

${ }^{23}$ Diecezja chelmińska, s. $41 \mathrm{nr} 28$ (,umarł w Wąbrzeźnie 1 XI 1613 r., pochowany w Chełmży”); HC, t. 4, s. 169 („obiit anno 1613“); Szostkiewicz, Katalog biskupów obrzqdku łacińskiego, s. 488 (,zmarł 1 XI 1613 r.”); J. M. Małecki, Konopacki Maciej (zm. 1613), wojewoda chetmiński, potem biskup chetmiński, PSB, t. 12, s. 550 (,zmarł 1 XI 1613 r. na zamku biskupim w Wąbrzeźnie”); Dola, Katalog arcybiskupów i biskupów, s. 260 nr 29 (,,zm. 1 XI 1613 r.”); Die Bischöfe des Heiligen Römischen Reiches 1448 bis 1648, s. 378 (H. J. Karp) („starb am 1 XI 1613 auf seiner bischöflichen Burg Briesen, die er ausgebaut hatte”); SBPN, t. 2, s. 438 (T. Oracki) („wracając z sejmi- 
ADP, AKKCh A 46, k. 69r

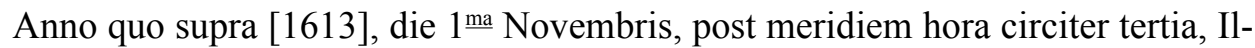
lustrissimus et Reverendissimus in Christo Pater, Reverendissimus Dominus Mathias a Conopat, episcopus Culmensis, senator dignissimus, Ecclesiae et universae Reipublicae Polonae apprime commodus, [...] in arce Fredecensi animam Deo reddidit.

\section{9}

Kostka Piotr biskup (Chetmża)

$+25 I 1595^{24}$

ADP, C 1 - [Codex epistolaris episcoporum Culmensium 1562-1611], k. 116r-v nr 346 (list kanonika Odyneta Perrenot do kapituly katedralnej chetmińskiej - kopia)

In maximo meo dolore atque luctu, quem de Reverendissimi Domini et benefactoris mei morte percipio, qui ante duas horas a Deo Optimo Maximo evocatus ex hac vita, ad aeternas illas beatasque sedes commigravit, intermittere pro officio meo non possum, quin de hoc ipsius obitu Reverendas Dominationes Vestras mox certiores faciam. [...] Datum Lubaviae, ipso die Conversionis Beati Pauli Apostoli, vesperis, anno 1595 .

\section{0}

Krasiński Jan biskup (Loryma)

$+[25]$ III $1757^{25}$

ku toruńskiego nagle zachorował i zmarł 1 XI 1613 r. w Wąbrzeźnie”); Nitecki, Biskupi Kościoła w Polsce, kol. 212 (,zm. 1 XI 1613 r.”).

${ }^{24}$ HC, t. 3, s. 182 (brak daty śmierci); Diecezja chetmińska, s. $40 \mathrm{nr} 25$ („,́́mierć zabrała go w dniu 25 I 1595 r.”); Szostkiewicz, Katalog biskupów obrzqdku łacińskiego, s. 491 (,umarł 25 I 1595 r.”); A. Tomczak, Kostka Piotr (ok. 1532-1595), biskup chetmiński, PSB, t. 14, s. 355 (,zmarł w Lubawie 25 I 1595 r.”); Dola, Katalog arcybiskupów i biskupów, s. 260 nr 26 (,zm. 25 I 1595 r.”); SBPN, t. 2, s. 468 (W. Odyniec) („,zm. w Lubawie 25 I 1595 r.”); Die Bischöfe des Heiligen Römischen Reiches 1448 bis 1648, s. 379 (H. J. Karp) (,starb am 25 I 1595 und wurde im Dom zu Kulmsee beigesetzt”); Słownik biograficzny kapituly warmińskiej, s. 126 (A. Kopiczko) (,zm. 25 I 1595 r. i został pochowany w Chełmży”); Nitecki, Biskupi Kościoła w Polsce, kol. 218 (,zm. 25 I 1595 r.").

${ }^{25}$ W. F. Pawelec, Biskupstwo chetmskie (szkic historyczny), cz. [7], „Wiadomości Diecezjalne Lubelskie”, 17 (1935) nr 1, s. 23, nr 9 (,,w 1754 r. zrzekł się sufraganii chełmskiej i innych godności, osiadł w Tranenbergu na Warmii i do końca życia oddał się dziełom pobożności. Umarł dnia $25 \mathrm{~V}$ 1757 r., pochowany został w Tranenbergu"); Szostkiewicz, Katalog biskupów obrzqdku tacińskiego, s. 493 („,umarł 25 III 1763 r.”); HC, t. 7, s. 265 (,obiit ante 22 Ianuarii 1760”); J. Staszewski, Krasiński Jan Chryzostom Stanisław (1695-1757), biskup tytularny lorymeński, sufragan chetmski, [w:] PSB, t. 15, Wrocław - Warszawa - Kraków 1970, s. 182 (,zmarł 26 III 1757 r.; inne daty, występujące w literaturze przedmiotu, są błędne"); Stownik biograficzny kapituły warmińskiej, s. 131 (A. Kopiczko) („,zm. 25 III 1757 r.”); Nitecki, Biskupi Kościoła w Polsce, kol. 226 („,zm. 26 III 
AAWO, AK Ab 36 - [Litterae episcoporum Adami Stanislai Grabowski et Ignatii Krasicki 1756-1772], k. 8r (list biskupa A.S. Grabowskiego do kapituly warmińskiej z daty: Heilsbergae, 26 III 1757).

Tristis nuntius de obitu Illustrissimi et Reverendissimi Domini Joannis Krasinski, episcopi Lorimensis et istius ecclesiae canonici, maxima nos maestitia implevit; summo enim amici viri, qui plurimis virtutibus et animi dotibus genus suum illustre exornabat, desiderio tenemur; sed quid prosunt quaestus, quid lacrymae, cum non resurget nisi in resurrectione in novissimo die? Hanc ei gloriam ad Altare Dei precemur, eandemque aeternitatis viam, abiecta terrenarum rerum cura, praesertim ad regias Agni dapes proxime accessuri, odio et dissensionibus procul sepositi, serio meditemur; nescimus enim diem neque horam.

Kretkowski Feliks Ignacy biskup (Chetmża)

+6 XII $1730^{26}$

ADP, AKKCh A 49, k. 134 r (Obitus Illustrissimi et Reverendissimi Domini Felicis Kretkowski, episcopi Culmensis et Pomesaniae)

Qui Illustrissimus [Dominus Felix Ignatius Kretkowski, episcopus Culmensis], plenus dierum et meritorum tam in Regno [Poloniae], quam in Ecclesia, ex referendario Regni factus episcopus Culmensis, extra dioecesim profectus, die 6 . mensis Decembris [1730], festo sancti Nicolai Ep[iscopi], munitus Sacramentis, diem clausit extremum. Requiescat in sancta pace.

\section{2}

Kuczborski Jan biskup (Chetmża)

$+30 / 31$ III $1624^{27}$

1757 r.”). Por.: „Kurier Polski”, 1757, nr XIV, s. [2]; Prokop, Wiadomości do biografii biskupów, s. 306 .

${ }^{26}$ Diecezja chetmińska, s. 46 nr 42 (,,umarł 6 XII 1730 r. w dobrach swoich kujawskich; pochowany w Chełmży”); HC, t. 5, s. 178 („obiit 6 Decembris 1730”); Szostkiewicz, Katalog biskupów obrzqdku łacińskiego, s. 493 (,zmarł 6 VII 1730 r.”); J. Staszewski, Kretkowski Feliks Ignacy (1657-1730), biskup chetmiński, PSB, t. 15, s. 280 (,zmarł 6 XII 1730 r. w rodzinnych Kretkach w ziemi dobrzyńskiej”); Dola, Katalog arcybiskupów i biskupów, s. $260 \mathrm{nr} 44$ („,zm. 6 XII 1730 r.”); Die Bischöfe des Heiligen Römischen Reiches 1648 bis 1803, s. 244 (H. J. Karp) (,starb am 6 XII 1730 auf seinem Familiengut Kretki in Dobriner Land"); Urzędnicy centralni i nadworni Polski, s. 177 (,† 6 XII 1730”); SBPN, t. 2, s. 503 (S. Achremczyk) (,zmarł w dziedzicznych dobrach Kretkach 6 XII 1730 r. Pochowany został 4 I 1731 r. w katedrze chełmżyńskiej”); Nitecki, Biskupi Kościoła w Polsce, kol. 227 („,zm. 6 XII 1730 r.”). Por. „Kurier Polski”, 1730, nr LII, s. 227; Prokop, Wiadomości do biografii biskupów, s. 306.

${ }^{27}$ Diecezja chetmińska, s. 41 nr 29 (,umarł 31 III 1624 r. w Lubawie, pochowany w toruńskim kościele św. Jana"); HC, t. 4, s. 169 (brak daty śmierci); Szostkiewicz, Katalog biskupów obrzqdku łacińskiego, s. 495 („,umarł 31 III 1624 r.”); W. Müller, Kuczborski Jan (ok. 1572-1624), 
ADP, AKKCh A 46, k. $155 r$

In capitulo [1 IV 1624] lectae sunt literae Admodum Reverendi Domini Joannis Mikołayczewski, quibus denuntiat Illustrissimum et Reverendissimum Dominum Joannem Kucborskij in arce Lubaviensi, die ultima Martii [= 31 III 1624], post mediam noctem, ultimum diem clausisse, cuius animae Deus sit propitius.

ADP, C 8-[Acta curiae 1622-1624], k. 57 r (tamże, k. 58r-64v: Testamentum et ordinatio ultimae voluntatis Illustrissimi et Reverendissimi Domini, Domini Joannis Kucborski, Dei gratia episcopi Culmensis et Pomesaniae, anno Domini 1623, die 13. Decembris)

Mors [episcopi Culmensis Joannis Kuczborski] subsecuta 30. Martii eodem anno 1624, praesente Illustrissimo et Reverendissimo Domino Henrico Firlei de Dambrowice, episcopo Plocensi ac nominato archiepiscopo Gnesnensi.

\section{3}

Kurdwanowski Jan Franciszek biskup (Marocco)

+28 XII $1729^{28}$

AAWO, AK Acta Cap. 15 - Acta capitularia a die 2 $1^{\text {ma }}$ Januarii 1723 ad diem $23^{\text {tiam }}$ Decembris 1730, k. 306v-307r (Capitulum repentinum die 29 Decembris 1729)

Lectum est testamentum una cum codicillis Illustrissimi et Reverendissimi olim Joannis Francisci Kurdwanowski, episcopi Maronensis, praepositi canonici Varmiensis et Cracoviensis, hesterna die [= 28 XII 1729], circa mediam sextam vespertinam, in Domino defuncti [...]. Hodie vigiliae repetinae cum Missa de requiem in crastinum pro anima Illustrissimi in Domino defuncti solenniter peragentur.

biskup chetmiński, PSB, t. 16, s. 72 (,zmarł 31 III 1624 r. w Lubawie”); Dola, Katalog arcybiskupów i biskupów, s. 260, nr 30 („,zm. 31 III 1624 r.”); SBPN, t. 2, s. 530 (A. Nadolny) (,zm. 31 III 1624 r. w Lubawie"); Die Bischöfe des Heiligen Römischen Reiches 1448 bis 1648, s. 387 (H. J. Karp) (,starb am 31 III 1624 in Löbau und wurde in der Johanniskirche zu Thorn beigesetzt”); Nitecki, Biskupi Kościoła w Polsce, kol. 234 („,zm. 31 III 1624”). Zob. nadto: Bazylika katedralna świętych Janów w Toruniu, red. M. Biskup, Toruń 2003, s. 216.

${ }^{28}$ HC, t. 5, s. 257 (,obiit 5 Ianuarii 1730”); Szostkiewicz, Katalog biskupów obrzqdku łacińskiego, s. 496 (,zmarł 5 I 1730 r.”); J. Staszewski, Kurdwanowski Jan Franciszek (1645-1729), biskup sufragan warmiński, PSB, t. 16, s. 233 (,,zmarł 28 XII 1729 r. (Niesiecki i Hierarchia Catholica 5 I 1730 r. - błędnie)"); Die Bischöfe des Heiligen Römischen Reiches 1648 bis 1803, s. 253 (A. Triller) (,starb am 28 XII 1729 in Frauenburg”); Urzędnicy centralni i nadworni Polski, s. 178 (,† 28 XII 1729”); Stownik biograficzny kapituly warmińskiej, s. 140 (A. Kopiczko) („,zm. 28 XII 1729 r.”); Nitecki, Biskupi Kościoła w Polsce, kol. 236 (,zm. 28 XII 1729 r.”). Zob. nadto: L. Zarewicz, Zakon kamedutów, jego fundacje i dziejowe wspomnienia w Polsce i na Litwie, Kraków 1871, s. 93-94, przyp. *. 
AAWO, AK Acta Cap. 17 - Acta capitularia a die $7^{\text {ma }}$ Novembris 1741 ad diem $22^{\frac{\text { dam }}{2}}$ Decembris 1747 anni, s. 608-609 (Capitulum extraordinarium die $3^{\text {tia }}$ mensis Octobris 1746 celebratum)

Cum Illustrissimus et Reverendissimus Dominus suffraganeus, praepositus Varmiensis et praeses capituli, Dominus Michaël Remigiusz Łaszewski, post circiter 4 septimanarum passam infirmitatem, omnibus prius sacramentis rite provisus, cui viaticum die $1 \stackrel{\mathrm{ma}}{\mathrm{ma}}$ Octobris, assistente clero cathedrali tum et Reverendissimis Dominis capitularibus, Reverendissimus Dominus decanus processionaliter deductus ad curiam Illustrissimi et Reverendissimi Domini supradicti, eidem ministraverat, heri [ $=2$ X 1746] tribus quadrantibus ad primam post meridiem diem clausit extremum, pro cuius anima statim vigiliae repentinae post vesperas et completorium, huius Nocturni, quamvis Festo Dedicationis Ecclesiae, decantatae fuerant, posito in medio chori catafalco cum infula et pastorali, hodie vero Missa solemnis de requiem per Reverendissimum Dominum Ignatium Czarlinski absoluta, placuit procedere ad apertionem testamenti piae memoriae Illustrissimi et Reverendissimi Domini praepositi, quod Reverendissimo Capitulo exhibuit Reverendissimus Dominus Czarlinski uti et tanquam nominatus executor una cum Reverendissimo Domino canonico Hugvenin [...]. Crastinam diem sepultura prefixit et quidem post Missam maturam [...], exuviae locabuntur in fornice.

\section{5}

Mathy (Matthy) Ignacy Stanistaw biskup (Chetmża)

$+20 \mathrm{~V} 1832^{30}$

${ }^{29}$ Szostkiewicz, Katalog biskupów obrzqdku łacińskiego, s. 504 (brak daty zgonu); HC, t. 6, s. 272 („obiit «aliquot annos» ante 26 Februarii 1765”); T. Oracki, Stownik biograficzny Warmii, Prus Ksiązęcych i Ziemi Malborskiej do polowy XV do końca XVIII wieku, t. 2, Olsztyn 1988, s. 24 (,zm. 2 X 1746 r. we Fromborku”); Die Bischöfe des Heiligen Römischen Reiches 1648 bis 1803, s. 262 (A. Triller) (,starb am 2 X 1746 in Frauenburg”); Stownik biograficzny kapituly warmińskiej, s. 158 (A. Kopiczko) („zm. 2 X 1746 r. we Fromborku”); Nitecki, Biskupi Kościoła w Polsce, kol. 262 (,zm. w r. 1746”).

${ }^{30}$ Diecezja chetmińska, s. 50, nr 50 (,umarł 20 V 1832 r. w Pelplinie, pochowany w katedrze”); HC, t. 7, s. 169 („,obiit 20 Maii 1832”); B. Kumor, Mathy Ignacy Stanistaw (1765-1832), biskup chetmiński, PSB, t. 20, s. 201 (,zmarł 20 V 1832 r. w Pelplinie”); Dola, Katalog arcybiskupów i biskupów, s. $261 \mathrm{nr} 52$ (,zm. 20 V 1832 r.”); Die Bischöfe der deutschsprachigen Länder 1785/1803 bis 1945, s. 486 (E. Piszcz) (,starb am 20 V 1832 in Pelplin und wurde in der dortigen Kathedrale beigesetzt”); Stownik biograficzny kapituly warmińskiej, s. 165 (M. Borzyszkowski) (,zm. 20 V 1833 r.; pochowany w katedrze w Pelplinie”); SBPN, t. 3, s. 172 (B. Kumor) (,zm. 20 V 1832 r. w Pelplinie, pochowany został w podziemiach tamtejszej katedry"); Nitecki, Biskupi Kościoła w Polsce, kol. 286 (,zm. 20 V 1832 r.”). 
ADP, AKKCh A 51 - Acta Venerabilis Capituli Culmensis ab anno Domini millesimo septingentesimo nonagesimo tertio [1793-1832], $k$. 290r.

Diurna sessio convocata est [20 V 1832] ob subsecutam hora pomeridiana secunda mortem Illustrissimi Excellentissimi loci ordinarii Stanislai de Mathy.

\section{6}

\section{Opaliński Kazimierz Jan biskup (Diocletiana - Chetmża) †20/21 VII 16931}

ADP, AKKCh A 47, s. 47 (sesja kapituly w dniu 23 VII 1693 r.); zob. również: ADP, C 25, k. 2 r (gdzie informacja o nominacji Kazimierza Szczuki na biskupstwo chetmińskie ,,post obitum die vigesima prima Julii anno Domini millesimo sexcentesimo nonagesimo tertio Illustrissimi et Reverendissimi Domini Casimiri Joannis de Bnin Opalenski”)

In hoc capitulo lectae sunt literae a Reverendissimo Domino suffraganeo Culmensi [Thoma Skotnicki] missae, quibus defert Venerabili Capitulo Illustrissimum et Reverendissimum Dominum Casimirum de Bnin Opalinski, episcopum Culmensem et Pomesaniae, Sacramentis rite munitum, die 20. mensis Julii, hora nona ante meridiem, Turoviae obiisse, facta dispositione rerum suarum per $[\ldots]$ testamentum.

\section{7}

Pilchowicz Wojciech biskup (Hippo)

$+1 V 1665^{32}$

${ }^{31}$ Diecezja chetmińska, s. 45 nr 38 (,umarł 21 VII 1693 r. w Turowie; pochowany w kościele klasztornym łąkowskim”); HC, t. 5, s. 177 („obiit mense Iulio 1693”); Szostkiewicz, Katalog biskupów obrzqdku łacińskiego, s. 527 (,zmarł 21 VII 1693 r.”); Nowacki, Dzieje archidiecezji poznańskiej, t. 2, s. 108 (,zm. 21 VII 1693”); Dola, Katalog arcybiskupów i biskupów, s. $260 \mathrm{nr} 40$ (,zm. 21 VII 1693 r."); E. Piszcz, Opaliński Kazimierz Jan z Bnina (1639-1693), biskup chetmiński, PSB, t. 24, s. 87 (,zmarł w Turowie w wyniku ataku apopleksji między 19 a 22 VII 1693 r.”); Die Bischöfe des Heiligen Römischen Reiches 1648 bis 1803, s. 328 (H. J. Karp) („er starb zwischen dem 19 und 22 VII 1693 in seiner Residenz auf dem Landgut Thurau in der Nähe von Löbau"); SBPN, t. 3, s. 263 (A. Nadolny) (,w ostatnich latach życia mieszkał w swym majątku w Turowie, gdzie zmarł 20 VII 1693 r.”); Nitecki, Biskupi Kościoła w Polsce, kol. 322 (,,zm. 21 VII 1693 r.”).

${ }^{32}$ HC, t. 4, s. 204 (brak daty śmierci); Szostkiewicz, Katalog biskupów obrzadku łacińskiego, s. 534 (,zmarł 1 V 1665 r.”); H. E. Wyczawski, Pilchowicz (Pilchowic) Wojciech (1600-1665), sufragan warmiński, PSB, t. 26, s. 245 („podczas pobytu w Łyszkowicach w r. 1665 nagle zachorował i zmarł między 27 IV a 2 V; pochowany w podziemiach kolegiaty łowickiej”); Oracki, Stownik biograficzny Warmii, t. 2, s. 77 (,zm. 1 V 1665 r. w Łyszkowicach, pochowany w Łowiczu”); Die Bischöfe des Heiligen Römischen Reiches 1648 bis 1803, s. 344 (A. Triller) („† April 1665 in Łyszkowice bei Lowitsch auf der Rückreise von einem Besuch bei W. Leszczyński”); Stownik biograficzny kapituły warmińskiej, s. 187 (A. Kopiczko) (,zm. 1 V 1665 r. w Łyszkowicach, pochowany w Łowiczu”); Nitecki, Biskupi Kościoła w Polsce, kol. 344 (,zm. 1 V 1655 r.”). 
AAWO, AB H 37a, s. 511-512 nr 18 (zob. również: AAWO, AK Acta Cap. 8-Acta capitularia a die $11^{\frac{\mathrm{ma}}{\mathrm{a}}}$ Martii $1661^{\mathrm{mo}}$ ad diem 22 ${ }^{\frac{\mathrm{dam}}{a}}$ Martii 1674, k. 81r, 83r)

[Adalbertus Pilchowicz, episcopus Hipponensis, suffraganeus Varmiensis, archipresbyter Heilsbergensis, qui] raro ad hanc ecclesiam sibi concreditam residebat sed curam animarum per commendatarios administrabat, [...] mortuus est in Polo-

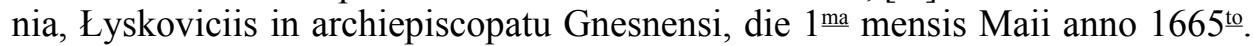
Sepultus Łoviciis in ecclesia collegiata.

\section{8}

Rogowski Iwo Onufry biskup (Camachus)

$+23 I 1806^{33}$

ADP, C 67, s. VI nr 106. Zob. również: ADP, AKKCh A 70-[Cathalogus canonicorum cathedralium Culmensium 1601-1927. Catalogus episcoporum Culmensium 1215-1856], s. 11 (1806, die 23. Januarii obiit Culmsae)

Illustrissimus, Reverendissimus Dominus Ivo Onuphrius de Rogowski, episcopus Camacensis, suffraganeus et archidiaconus cathedralis Culmensis, praepositus Fürstenwerdensis et Thiergardensis, obiit die $23^{\text {tia }}$ Januarii 1806.

ADP, AKKCh A 55 - [Anniversaria et fundationes XVII w. - 1809 r.], k. 57r. Zob. również: ADP, $C 74$ - Collectio instrumentorum, facultatum etc. diversi generis ab anno 1796 usque ad annum 1814, s. 434-435 (dokument nominacyjny na sufraganię chetmińska dla prepozyta katedralnego Jana Wilkxyckiego z daty: Nieżuchowo, 3 II 1806 r., rozpoczynajacy się od stów: „, Quo cum Illustrissimus ac Reverendissimus Ivo Onuphrius de Rogowski, episcopus Camacensis, suffraganeus et archidiaconus cathedralis Culmensis, sub die $23^{\text {tia }}$ mensis Ianuarii proxime elapsi morte obierit”, itd.)

Ivo de Rogowski, suffraganeus episcopus et archidiaconus cathedralis Culmensis, obiit die $23^{\text {ta }}$ Januarii 1806 , Culmsae.

Rudnicki Szymon biskup (Warmia)

+4 VII $1621^{34}$

${ }^{33}$ Frydrychowicz, Die Culmer Weihbischöfe, s. 32 („starb am 23 I 1806”); Mańkowski, Prałaci i kanonicy, s. 174 (,,umarł 23 I 1806 r.”); HC, t. 6, s. 142 („obiit 23 Ianuarii 1806”); Nitecki, Biskupi Kościoła w Polsce, kol. 379 (,,zm. 23 I 1806 r.”).

${ }^{34}$ HC, t. 4, s. 359 (brak daty śmierci); Szostkiewicz, Katalog biskupów obrzqdku łacińskiego, s. 549 (,umarł 4 VII 1621 r.”); Dola, Katalog arcybiskupów i biskupów, s. 295 nr 26 (,zm. 4 VII 1621 r.”); Oracki, Stownik biograficzny Warmii, t. 2, s. 121 (,zm. 4 VII 1621 r. w Lidzbarku Warmińskim, pochowany we Fromborku"); H. Kowalska, Rudnicki Szymon (1552-1621), biskup warmiński, PSB, t. 32, s. 654 (,zmarł 4 VII 1621 r. w Heilsbergu”); Urzędnicy centralni i nadworni Polski, s. 199 (,† 4 VII 1621”); Achremczyk, Marchwiński, Przeracki, Poczet biskupów warmińskich, s. 129-134 (brak daty dziennej śmierci!); Die Bischöfe des Heiligen Römischen Reiches 1448 bis 1648, s. 601 
AAWO, AB A 8-[Acta consistorii Varmiensis 1606-1625], s. 415

Illustrissimus ac Reverendissimus Dominus Simon Rudnicki, episcopus Varmiensis, die IV. mensis Julii anni proxime praeteriti MDCXXI in Domino quiescit diemque clausit extremum.

$A A W O, A B E b 81$, k. 10 r

Simon Rudnicky, Reverendissimus episcopus Varmiensis, patriae parens et dominus gratiosissimus, anno 1621, die $4^{\text {ta }}$ Julii pie moriens, pro anniversaria memoria Venerabili Capitulo [Guttstadiensi] ex testamento reliquit trecentas marcas.

AAWO, AK Acta Cap. 4 - Acta capitularia ab anno 1614, die 18. Augusti, usque ad annum 1631, diem 27. Augusti, k. 54v

Illustrissimus ac Reverendissimus Dominus episcopus [Varmiensis Simon Rudnicki] [...] pie in Domino obdormivit 4. Julii [1621], hora circiter quarta pomeridiana.

20

Rydzyński Franciszek Ksawery biskup (Nilopolis - Chetmża)

$+16 / 17 \times 1814^{35}$

(H. J. Karp) („starb am 4 VII 1621 in Heilsberg”); Stownik biograficzny kapituly warmińskiej, s. 209 (A. Kopiczko) (,zm. 4 VII 1621 r. w Lidzbarku, pochowany we Fromborku”); SBPN, t. 4, s. 107 (D. Bogdan) (,zm. 4 VII 1621 r. w Lidzbarku Warmińskim, pochowany został w katedrze fromborskiej”); Nitecki, Biskupi Kościoła w Polsce, kol. 385 („,zm. 4 VII 1621 r.”). Por. edycję w „Roczniku Dobromiejskim", 1 (2007) s. 60-61, nr XVIII. Także: Heide, Archiwum dawne i nowe, s. 23-24, 102; Leo, Dzieje Prus, s. 518-519; Oesterrreich, Treter, Treter, Kronika lidzbarska, s. 125. Nadto: Obłąk, Katedra we Fromborku, bp. (fot. Ptyta nagrobna biskupa Szymona Rudnickiego przed wielkim oltarzem).

${ }^{35}$ Frydrychowicz, Geschichte der Cisterecienserabtei Pelplin, s. 123 („,er starb im 81. Lebensjahr am 17 X 1814 auf seinem Gute Nieżuchow”); Diecezja chetmińska, s. 49 nr 49 (,umarł mając lat 81, dnia 17 X 1814 r. w Nieżuchowie; pochowany w kościele chodzieskim, którego niegdyś był proboszczem”); Nowacki, Dzieje archidiecezji poznańskiej, t. 2, s. $190 \mathrm{nr} 35$ (,umarł 16 X 1814 w Nieżychowie, [a] pochowany został - w myśl swej ostatniej woli - w kościele parafialnym w Chodzieży, gdzie uczczono jego pamięć nagrobkiem z portretem”); HC, t. 6, s. 189 („obiit 17 Octobris 1814”); Dola, Katalog arcybiskupów i biskupów, s. 261 nr 51 (,zm. 17 X 1814 r.”); Die Bischöfe der deutschsprachigen Länder 1785/1803 bis 1945, s. 639 (E. Piszcz) (,starb am 16 X 1814 in Nieżychowo"); B. Kumor, Rydzyński Franciszek Ksawery Piotr (1734-1814), biskup chelmiński i opat pelpliński, PSB, t. 33, s. 454-455 (,zmarł w Nieżychowie 17 X 1814, został pochowany w kościele parafialnym w Chodzieży"); Słownik biograficzny kapituły warmińskiej, s. 211 (M. Borzyszkowski) (,zm. 10 X 1814 r.”); SBPN, t. 4, s. 126 (A. Nadolny) (,zm. 17 X 1814 r. w Nieżychowie, został pochowany w kościele parafialnym w Chodzieży”); Nitecki, Biskupi Kościoła w Polsce, kol. 389 (,zm. 17 X 1814 r.”). 
ADP, AKKCh A 51 - Acta Venerabilis Capituli Culmensis ab anno Domini millesimo septingentesimo nonagesimo tertio [1793-1832], k. 211r

Obitus Illustrissimi, Excellentissimi, Reverendissimi Domini Xaverii comitis de Verbno Rydzyński, episcopi Culmensis et Mariaeburgensis, abbatis commendatarii Pelplinensis, ordinum Sancti Stanislai et Aquilae Rubrae equitis, die 16/17 Octobris 1814 subsecutus, cuius anima requiescat cum sanctis.

ADP, C 67, s. VIII nr 165

Illustrissimus, Excellentissimus ac Reverendissimus Franciscus Xaverius comes de Werbno Rydzyński, episcopus Culmensis et Pomesaniae, abbas commendatarius Pelplinesis, custos Gnesnensis et Varmiensis, eques Ordinum Sancti Stanislai et Aquilae Rubrae, ${ }^{a-N i e z ̇ u c h o w i a e ~}{ }^{-a}$ obiit die 17. Octobris, hora 2" matutina, 1814, annorum suae aetatis 81, episcopatus 19 annorum. Sepultus in opido Chodzież, districtu Węgrowiecensi.

21

Soltyk Maciej Aleksander biskup (Mactaris)

+8 XII 1749 36

ADP, AKKCh A 12 - [Acta capituli Culmensis ab anno 1742 ad annum 1752], s. 203-204 (Obitus Illustrissimi, Reverendissimis Domini Mathiae Sottyk, Dei et Apostolicae Sedis gratia episcopi Margaritensis, suffraganei, archidiaconi et officialis generalis Culmensis, praepositi ecclesiarum metropolitanae Gnesnensis ${ }^{b-}[\ldots]^{-b}$, Lanciciensis et Thorunensis, canonici Varmiensis)

Qui Illustrissimus et Reverendissimus Dominus [Matthias Alexander Sołtyk] communi et inevitabili subiectus fato post completos aetatis suae non minus numero quia 71., quem virtutibus et meritis commendatos annos in canonicatu Culmensis ab Illustrissimo olim et Reverendissimo demum Celsissimo primate Theodoro Potocki, pro tempore episcopo Culmensi et Pomesaniae, ob dotes animi sui anno 1702 promotus, custodiali primum, post archidiaconali munere ac suffraganeali insignitus dignitate, meritissimus in Ecclesia Dei, in laboribus indefessus, pater et praeses capituli dignus, quem posterorum fama loquar, affectione et ${ }^{\mathrm{c}}$

a-a Nadpisane. ${ }^{b-b}$ Karta uszkodzona.

${ }^{36}$ R. Frydrychowicz, Die Culmer Weihbischöfe, s. 24-25 („starb er am 8 XII 1749, im 71. Lebensjahr und im 21. seiner bischöflichen Würde”); A. Mańkowski, Prałaci i kanonicy, s. 199 („umarł 8 XII 1749 r.”); HC, t. 5, s. 236 („obiit ante 25 Maii 1750”); Szostkiewicz, Katalog biskupów obrzqdku łacińskiego, s. 557 („,zmarł 8 XII 1749 r.”); Die Bischöfe des Heiligen Römischen Reiches 1648 bis 1803, s. 472 (H.J. Karp) („,starb am 8 XII 1749”); Stownik biograficzny kapituly warmińskiej, s. 229 (A. Kopiczko) („,zm. 8 XII 1749 r.”); Nitecki, Biskupi Kościoła w Polsce, kol. 411 („,zm. 8 XII 1749 r.'); J. Dygdała, Soltyk Maciej Aleksander (1679-1749), biskup sufragan chetmiński, [w:] PSB, t. 40, Warszawa - Kraków 2000-2001, s. 408 („zmarł w Chełmnie 8 XII 1749 r.”). 
phtysi ${ }^{-\mathrm{c}}$ tactus, post breve infirmitatis suae tempus, nempe intra dies quatuor, ipso festo Immaculatae Conceptionis Beatissimae Virginis Mariae singularissimae omnis de hac vita decedentium patronae, nocte, intra horam 11 et 12 , confessus et dispositus, circa praesentiam Perillustrium praelatorum condolentium, relicto testamento, animam Deo redduxit, cui lux aeterna luceat.

Szczuka Kazimierz biskup (Chetmża)

+30 VI $1694^{37}$

ADP, C 25, k. $151 r$ (Decessus ex hac vita Illustrissimi Domini loci ordinarii)

Mercurii, die 30. mensis Junii [1694]. Illustrissimus ac Reverendissimus Dominus, Dominus Casimirus de Szczuki Szczuka, Dei et Apostolicae Sedis gratia episcopus Culmensis et Pomesaniae, abbas Paradisiensis, annorum aetatis suae septuaginta duorum, absoluto per quinque menses episcopalis muneris in hac dioecesi officio, plenus annorum, laborum circa vineam Domini, virtutum et meritorum, hodie [= 30 VI 1694] e terrestri ad caelestem paradisum translatus, orphanae diaecesi et omnibus Christifidelibus maxime tamen pauperibus, quorum praecipuus benefactor extabat, moerorem reliquit.

ADP, AKKCh A 47, s. 124 (Obitus Illustrissimi Domini [Casimiri] Szczuka, episcopi Culmensis et Pomesaniae)

Die 1. Julii [1694] congregati capitulariter Perillustres Domini indoluerunt super fato et obitu Illustrissimi et Reverendissimi Domini Casimiri Szczuka, episcopi Culmensis et Pomesaniae, abbatis Paradisiensis. Qui, ut ex literis Perillustris Domini Custodis ac relatione Perillustris Domini praepositi constat, heri, ultima scilicet mensis Junii [= 30 VI 1694], hora quarta a prandis, Culmae, inter sacerdotum et religiosorum choros, patris et defensoris egenorum mortem lugentium, spiritum Deo reddidit vere virgineus Casimirus.

${ }^{\mathrm{c}-c}$ Wyraz nieczytelny (zamazany).

${ }^{37}$ Diecezja chetmińska, s. 45 nr 39 (,,30 VI 1694 r. przeniósł się 72-letni starzec do wieczności”); HC, t. 5, s. 178 („,obiit 30 Iunii 1694”); Szostkiewicz, Katalog biskupów obrzqdku łacińskiego, s. 563 (,umarł 30 VI 1694 r.”); Dola, Katalog arcybiskupów i biskupów, s. 260 nr 41 („,zm. 30 VI 1694 r.”); Die Bischöfe des Heiligen Römischen Reiches 1648 bis 1803, s. 497 (H.J. Karp) (,er wohnte im Kulmer Haus und ist dort auch am 30 VI 1694 nach kurzer Amtszeit gestorben"); SBPN, t. 4, s. 309 (S. Achremczyk) (,w czerwcu 1694 r. zachorował; zmarł 30 VI tr. w domu Księży Misjonarzy chełmińskich”); Nitecki, Biskupi Kościoła w Polsce, kol. 427 (,zm. 30 VI 1694 r.”). 
23

Szembek Krzysztof Jan biskup (Chetm/Krasnystaw - Przemyśl - Warmia)

+16 III $1740^{38}$

AAWO, $A B$ H 42, s. 165

[Christophorus Joannes Szembek, episcopus Varmiensis], finta visitatione generali, dispositionem fecit denuo celebrandi synodum celebrassetque anno $1740^{\mathrm{mo}}$ nisi die $16^{\text {ta }}$ Martii eiusdem anni Heilsbergae in arce paralysi tactus et subitanea et improvisa morte praeventus ex hoc saeculo arumnoso ad aeternae vitae beatitudinem migrasset anno aetatis sexagesimo primo, cum praefuisset Varmiae annis sedecim.

AAWO, AK Acta Cap. 16 - Acta capitularia ab anno 1731, die $16^{\text {mo }}$ Januarii, ad annum 1741, die $6^{\underline{t a}}$ Novembris [1733-1741], $k .358 v$ (Capitulum repentinum hora $4^{\text {ta }}$ a meridie die $17^{m a}$ Martii 1740)

Desigillatur et legitur epistola Reverendissimi Domini canonici Lingk [...] de data: Heilsbergae, die hesterna $16^{\text {ta }}$ currenti, cuius tenore significat, quod Celsissimus princeps episcopus [Christophorus Joannes Szembek], affectione gravi paralytica tactus in cassum adhibitis quibusvis remediis, hesterna die, sacramentis Ecclesiae rite provisus, hora $5^{\text {ta }}$ pomeridiana in Domino dies suos clauserit.

\section{4}

Szembek Stanisław arcybiskup (Dionysias - Włocławek - Gniezno)

+3 VIII $1721^{39}$

${ }^{38}$ Sarna, Biskupi przemyscy obrzadu tacińskiego, t. 2, s. 412 (,umarł 16 III 1740 r. w Heilsbergu”); HC, t. 5, s. 405 („obiit mense Martio 1740”); Szostkiewicz, Katalog biskupów obrzqdku łacińskiego, s. 565 („,zmarł 16 III 1740 r.”); Dola, Katalog arcybiskupów i biskupów, s. 296 nr 36 (,zm. 16 III 1740 r.”); Oracki, Stownik biograficzny Warmii, t. 2, s. 172 (,zm. 16 III 1740 r. w Lidzbarku Warmińskim, pochowany we Fromborku"); Die Bischöfe des Heiligen Römischen Reiches 1648 bis 1803, s. 499 (A. Triller) (,starb am 16 III 1740”); Urzędnicy centralni i nadworni Polski, s. 207 (,† 16 III 1740"); Achremczyk, Marchwiński, Przeracki, Poczet biskupów warmińskich, s. 173-176 (brak daty dziennej śmierci!); Słownik biograficzny kapituly warmińskiej, s. 245 (A. Kopiczko) (,zm. 16 III 1740 r. w Lidzbarku, pochowany we Fromborku”); SBPN, t. 4, s. 312 (S. Achremczyk) (,zm. 16 III 1740 r. w Lidzbarku Warmińskim”); Nitecki, Biskupi Kościoła w Polsce, kol. 431 („,zm. 16 III 1740 r.”). Por: „Kurier Polski”, 1740, nr CLXVII, s. [2]; nr CLXVIII, s. [1]-[3]; Heide, Archiwum dawne i nowe, s. 66, 128; Prokop, Wiadomości do biografii biskupów, s. 321. Nadto: Obłąk, Katedra we Fromborku, bp. (fot. Epitafium biskupa Krzysztofa Szembeka w prawej nawie bocznej).

${ }^{39}$ HC, t. 5, s. 210 („obiit 2 Augusti 1721”); Szostkiewicz, Katalog biskupów obrzqdku łacińskiego, s. 565 (,„zmarł 3 VIII 1721 r.”); Dola, Katalog arcybiskupów i biskupów, s. 264 nr 59 (,zm. 3 VIII 1721 r.”); Nitecki, Biskupi Kościoła w Polsce, kol. 431 (,zm. 3 VIII 1721 r.”); K.R. Prokop, Arcybiskupi gnieźnieńscy w tysiqcleciu, Kraków 2000, s. 243 (gdzie wskazana wcześniejsza literatura). 
AAWO, sygn. AK Ab 28 - [Listy różne 1712-1721], k. 194r. (całość - k. 193v-195v: Relacja prawdziwa o ostatniej chorobie i śmierci Jaśnie Oświeconego Księcia Jegomości Stanistawa na Stupowie Szembeka, z Bożej i Stolicy Apostolskiej [łaski] arcybiskupa gnieźnieńskiego, etc. etc.); zob. również: $k$. 198v-199r (Processus pro anima Celsissimi olim principis archiepiscopi Gnesnensis)

W sobotę [2 VIII 1721] Jaśnie Oświecony Książę [prymas Stanisław Szembek], zamknąwszy oczy, zdał się być konającym. Przyszedłszy tedy Jegomość Ksiądz Kanclerz pytał się go, jeśliby generalną chciał mieć absolucją, y nadto aby dał jaki znak żalu y skruchy, gdzie wtenczas Książę Jegomość rękę prawą Jegomości Księdza Kanclerza wziąwszy ścisnął, dając znak aktu skruchy. Zaczym pomieniony dał mu generalną absolucją. [...] O godzinie siódmej w niedzielę rano, dnia 3. Augusta tegoż roku 1721, począł konać. Podano mu tedy w ręce gromnicę. Zwykłą kommendacyą duszy Jegomość Ksiądz Kanclerz mówił, po skończonej [której] poszedł tenże Jegomość Ksiądz Kanclerz do kościoła, aby Mszą św. za konającego odprawił. Tymczasem Jegomość Ksiądz Kraszkowski, sufragan gnieźnieński, znowu kommendacyą zaczął, a gdy do tych słów przyszło: Subvenite ei Sancti, ocurite Angeli Domini etc., Jaśnie Oświecony Książę Jegomość ducha Bogu oddał o samej godzinie dziewiątej rano. Którego świątobliwa dusza niech żyje w błogosławieństwach wiecznych.

\section{5}

Szyszkowski Mikołaj biskup (Warmia)

+7 II $1643^{40}$

AAWO, AK Acta Cap. 6 - Acta capitularia ab anno Domini 1638, die 21 Januarii, usque ad annum 1645, diem $2^{\text {dam }}$ Augustii, inclusive, $k .116 \mathrm{v}$.

Ecclesia cathedralis [Varmiensis] orbata est post decessum ex hac vita Illustrissimi et Reverendissimi Domini episcopi Nicolai Szyszkowski die 7. Februarii $[1643]^{\mathrm{d}-}[\ldots]^{\mathrm{d}}$ in benedictione sit anima.

${ }^{\mathrm{d}-\mathrm{d}}$ Fragment tekstu uszkodzony.

${ }^{40}$ HC, t. 4, s. 359 (brak daty śmierci); Szostkiewicz, Katalog biskupów obrządku łacińskiego, s. 566 (brak daty zgonu); Dola, Katalog arcybiskupów i biskupów, s. 295 nr 28 (,zm. 7 II 1643 r.”); Oracki, Stownik biograficzny Warmii, t. 2, s. 178 (,zm. 7 II 1643 r. w Lidzbarku Warmińskim, pochowany we Fromborku”); Urzędnicy centralni i nadworni Polski, s. 208 (,† 7 II 1643”); Achremczyk, Marchwiński, Przeracki, Poczet biskupów warmińskich, s. 139-141 (brak daty dziennej śmierci!); Die Bischöfe des Heiligen Römischen Reiches 1448 bis 1648, s. 687 (H. J. Karp) („starb am 7 II 1643”); Słownik biograficzny kapituly warmińskiej, s. 250 (A. Kopiczko) (,zm. 7 II 1643 r. w Lidzbarku Warmińskim, pochowany we Fromborku"); Nitecki, Biskupi Kościoła w Polsce, kol. 436 (,zm. 7 II 1643 r.”). Por.: Heide, Archiwum dawne i nowe, s. 27, 104; Leo, Dzieje Prus, s. 524-525; Oesterrreich, Treter, Treter, Kronika lidzbarska, s. 131. Nadto: Obłąk, Katedra we Fromborku, bp. (fot. Ptyta nagrobna biskupa Mikołaja Szyszkowskiego przed wielkim ołtarzem). 
Wilkxycki Jan biskup (Flavias)

+15 V $1831^{41}$

ADP, AKKCh A 70 - [Cathalogus canonicorum cathedralium Culmensium 1601-1927. Catalogus episcoporum Culmensium 1215-1856], s. 12

Obiit 15. Maii 1831, sepultus in ecclesia cathedrali Pelplinensi.

\section{7}

Zatuski Andrzej Chryzostom biskup (Kijów - Płock - Warmia)

$+1 V 1711^{42}$

AAWO, AB A 25 - [Acta administationis episcopatus Vamiensis 1705-1712], k. 139v.

Sequntur nonnulla acta et decreta administratoralia sedis episcopalis post obitum piae memoriae Celsissimi principis Illustrissimi et Reverendissimi Domini Andreae Chrystostomi Załuski, episcopi Varmiensis, die 1. Maii 1711 Guttstadii pie in Domino defuncti, lata, me Francisco Ignatio Herr, Venerabilis Capituli Varmiensis secretario, ad eorundem conscriptionem adhibito notario.

AAWO, AK Acta Cap. 13 - Acta capitularia a die 24ta Martii anni 1706 ad diem $13^{\text {tiam }}$ Julii 1716, $k .115$ r (Anno 1711, die 1. Maii, capitulum extraordinarium sub concione)

Perillustris et Reverendissimus Dominus custos Venerabili Capitulo detulit se nuncium accepisse, quod Celsissimus princeps Illustrissimus Dominus loci ordinarius Andreas Chrysostomus Załuski, post aliquot dierum infirmitatem, videlicet

${ }^{41}$ Frydrychowicz, Die Culmer Weihbischöfe, s. 38 (,starb am 15. Mai 1831 im 68. Lebensjahre und zwar im Preußisch Stargard, wo er bei einem Artze Heilung gesucht hatte"); Mańkowski, Prataci i kanonicy, s. 224 (,umarł 15 V 1831 r., pochowany $20 \mathrm{~V}$ w kościele katedralnym”); HC, t. 7, s. 195 („obiit Pelplini mense Maio 1831“); Die Bischöfe der deutschsprachigen Länder 1785/1803 bis 1945, s. 817 (E. Piszcz) („,starb am 15 V 1831 in Preußisch Stargard”); Nitecki, Biskupi Kościoła w Polsce, kol. 482 (,zm. 15 V 1831 r.”).

${ }^{42}$ Nowowiejski, Plock. Monografia historyczna, s. $67 \mathrm{nr}$ LXIV (brak daty śmierci); HC, t. 5, s. 405 („obiit 1 Maii 1711 in loco Guttstadt”); Szostkiewicz, Katalog biskupów obrzqdku tacińskiego, s. 592 (,,zmarł 12 V 1711 r.”); Dola, Katalog arcybiskupów i biskupów, s. 296 nr 34 (,zm. 1 V 1711 r.”); Żebrowski, Zarys dziejów diecezji płockiej, s. 57 nr 58 (,zmarł 12 V 1711 r.”); Oracki, Stownik biograficzny Warmii, t. 2, s. 218 (,,zm. 1 V 1711 r. w Dobrym Mieście na Warmii”); Die Bischöfe des Heiligen Römischen Reiches 1648 bis 1803, s. 583 (A. Triller) („starb am 1 V 1711 im bischöflichen Palais zu Guttstadt, wo er oft residiert hatte"); Urzędnicy centralni i nadworni Polski, s. 57 nr 232 („† 1 V 1711”); Achremczyk, Marchwiński, Przeracki, Poczet biskupów warmińskich, s. 167 (,zm. 1 V 1711 r. w ulubionym przez siebie dworze biskupim w Dobrym Mieście”); Stownik biograficzny kapituly warmińskiej, s. 290 (A. Kopiczko) (,zm. 1 V 1711 r. w Dobrym Mieście”); SBPN, t. 4, s. 512 (S. Achremczyk) (,,zm. 1 V 1711 r. w Dobrym Mieście; pochowany został w kolegiacie dobromiejskiej 12 V tr.”); Nitecki, Biskupi Kościoła w Polsce, kol. 505 („,zm. 1 V 1711 r.”). Por. Heide, Archiwum dawne i nowe, s. 59, 121. 
affectionem seu inflammationem intestini, sacramentis rite dispositus et provisus, Guttstadii, in residentia sua episcopali, pie in Domino obierit.

Anno 1709ํㅡ Dominus Martinus Załuski, episcopus Rosmensis, suffraganeus ac praepositus Plocensis, decanus Pultoviensis, canonicus Cracoviensis, frater germanus Domini Andreae Załuski, principis episcopi Varmiensis, die $8^{\text {va }}$ mensis Aprilis, feria secunda post Dominicam in Albis [= 8 IV 1709], qua die festum Annuntiationis Beatissimae Virginis translatum celebrabatur, circa mediam quintam verspertinam, sacramentis provisus, cum plena resignatione in voluntatem Divinam et exemplari pietate, animam Deo reddidit in arce hac episcopali [Heilsbergensi]. Corpus eius exanime die $12^{\underline{m a}}$ eiusdem mensis in maxima frequentia cleri et populi ex arce delatum fuit mane media ad nonam in hanc ecclesiam parochialem [Heilsbergensem]. Exequias, Missam et ceremonias alias funebres absolvit memoratus loci ordinarius, quibus finitis ad interim delatum fuit cadaver in pretiosa tumba in ecclesiam Sancti Stanislai et ibidem depositum, donec mense Maio eiusdem anni Guttstadium translatum, et in ecclesia collegiata, ante altare maius, honorifice fuit sepultum.

Zbaski Jan Stanisław biskup (Przemyśl - Warmia)

$\uparrow 21 V 1697^{44}$

${ }^{43}$ Nowowiejski, Płock. Monografia historyczna, s. 80 nr 17 (,umarł w Gutstadzie w 1709 r.”); HC, t. 5, s. 335 („obiit ante 2 Maii 1710”); Szostkiewicz, Katalog biskupów obrzqdku tacińskiego, s. 594 („,umarł 8 IV 1709 r.”); Żebrowski, Zarys dziejów diecezji płockiej, s. 64 nr 19 („,zmarł 8 IV 1709 r.”); Nitecki, Biskupi Kościoła w Polsce, kol. 507 (,zm. 8 IV 1790 r. [sic]”). Por. Heide, Archiwum dawne i nowe, s. 57.

${ }^{44}$ Sarna, Biskupi przemyscy obrzqdu tacińskiego, t. 2, s. 380 (,dnia 21 V 1697 r., licząc lat 58 wieku, rozstał się z tym światem w Heilsbergu, o godzinie 9-tej wieczorem”); HC, t. 5, s. 405 („obiit 21 Maii 1697”); Szostkiewicz, Katalog biskupów obrzqqdku łacińskiego, s. 595 (,umiera 21 V 1697 r.”); Dola, Katalog arcybiskupów i biskupów, s. 295 nr 33 (,zm. 21 V 1697 r.”); Oracki, Stownik biograficzny Warmii, t. 2, s. 224 (,zm. 21 V 1697 r. w Lidzbarku Warmińskim, pochowany we Fromborku”); Die Bischöfe des Heiligen Römischen Reiches 1648 bis 1803, s. 586 (A. Triller) („starb am 21 V 1697”); Achremczyk, Marchwiński, Przeracki, Poczet biskupów warmińskich, s. 162 („,nagle zachorował i zmarł 21 V 1697 r.”); Stownik biograficzny kapituły warmińskiej, s. 291 (A. Kopiczko) (,zm. 21 V 1697 r. w Lidzbarku, pochowany we Fromborku”); SBPN, t. 4, s. 520 (S. Achremczyk) (,zmarł nagle w maju 1697 r.”); Nitecki, Biskupi Kościoła w Polsce, kol. 511 (,zm. 21 V 1697 r.”). Por. Heide, Archiwum dawne i nowe, s. 39, 116. 
AAWO, $A B$ H 37, s. 81; $A B$ H 37a, s. 86

Anno $1697^{\mathrm{mo}}$, die $21^{\mathrm{ma}}$ mensis Maii, vespere, duobus quadrantibus ad horam nonam, princeps episcopus Varmiensis Dominus Joannes Stanislaus Sbaski, sacramentis provisus, pie in Domino intestatus doloribus calculi obdormivit Heilsbergae in horto episcopali in palatio ab ipso magnifice extructo.

AAWO, $A B$ H 42, s. 139

[Joannes Stanislaus Zbąski, episcopus Varmiensis] intestatus obiit die $21^{\text {ma }}$ mensis Maii, vespere, duobus quadrantibus ad nonam, anno 1697mo. Sepultus honorificentissime Frauenburgi in ecclesia cathedrali in choro penes sacristiam.

AAWO, AK Acta Cap. 11 - Acta capitularia a die 17ma Junii 1693 ad diem 22 ${ }^{\text {ndam }}$ [Decembris] 1700 anni, $k .121$ r (Capitulum subitaneum die 22 Maji [1697], hora prima pomeridiana)

Literae Reverendissimi Domini suffraganei Lezenski, de data hesterna $[=21 \mathrm{~V}$ 1697], Heilsbergae, circa hora nona vespertina refertae, nuntiant sub eadem hora obiisse ibidem Celsissimum principem Illustrissimum Dominum Stanislaum [Joannem Zbąski] [...]. Doloroso animo et affectu hunc inopium nuntium accipientes Reverendissimi Domini [praelati et canonici] illico mandarunt pulsari omnes campanas tam cathedralis, quam parochialis, nec non et hospitalis ecclesiarum.

Zehmen Karol Ferdynand biskup (Lete)

+13 XII $1798^{45}$

ADP, C 67, s. IV nr 67

Illustrissimus ac Reverendissimus Dominus Carolus liber baro de Zehmann [sic], suffraganeus et praepositus cathedralis Varmiensis, parochus Thiergardensis, obiit Frauenburgi, die 13. Decembris 1798, aetatis anno[rum] 79.

${ }^{45}$ Szostkiewicz, Katalog biskupów obrzq̨dku łacińskiego, s. 596 (brak daty zgonu); HC, t. 6, s. 260 („obiit 13 Decembris 1798”); Oracki, Stownik biograficzny Warmii, t. 2, s. 225 (,zm. 3 XII 1798 r. we Fromborku"); Die Bischöfe des Heiligen Römischen Reiches 1648 bis 1803, s. 588 (A. Triller) (,starb am 13 XII 1798 in Frauenburg”); Słownik biograficzny kapituły warmińskiej, s. 291 (M. Borzyszkowski, A. Kopiczko) (,zm. 13 XII 1798 r.”); Nitecki, Biskupi Kościoła w Polsce, kol. 513 (,,zm. 3 XII 1798 r.”). 


\section{VARIA}

Bajer Andrzej Ignacy biskup (Chetmża)

ingres $29 I X 1759^{46}$

ADP, AKKCh A 11 - [Acta capituli Culmensis 1752-1760], s. 159 (Ingressus Illustrissimi, Excellentissimi et Reverendissimi Domini, Domini Andreae Ignatii de Broniewice Baier, Dei et Apostolicae Sedis gratia episcopi Culmensis et Pomesaniae, die 29 mensis Septembris [1759], scilicet ipso die festivo sancti Michaelis Archangeli)

Bokum (de Alten Bokum) Jan Kazimierz biskup (Przemyśl-Chetmża)

ADP, AKKCh A 48, s. 173 (Ingressus ad cathedram die 28 mensis Julii [1719] Excellentissimi, Illustrissimi et Reverendissimi Domini Joannis Casimiri de Alten Bokum, episcopi Culmensis et Pomesaniae, abbatis Czervenensis, procancellarii Regni)

${ }^{46}$ Diecezja chetmińska, s. $48 \mathrm{nr} 47$ („w dzień św. Michała [1759 r.] odbył ingres do katedry swojej”); Szostkiewicz, Katalog biskupów obrzqdku łacińskiego, s. 409 (brak daty ingresu); Dola, Katalog arcybiskupów i biskupów, s. 260 nr 49 („,ingres 29 IX 1759 r.”); Die Bischöfe des Heiligen Römischen Reiches 1648 bis 1803, s. 22 (brak daty ingresu); SBPN, t. 1, s. 54 (brak daty ingresu); Słownik biograficzny kapituły warmińskiej, s. 46 (brak daty ingresu); Nitecki, Biskupi Kościoła w Polsce, kol. 15 (,,ingres odbył 29 IX 1759 r.”). Por. „Addytament do Gazet”, 1759, nr 40, s. [2]; Prokop, Wiadomości do biografii biskupów, s. 295 przyp. 13.

${ }^{47}$ Diecezja chetmińska, s. 46 nr 41 („,osobiście objął zarząd diecezji 30 VII 1719 r.”); Kwolek, Bokum Jan Kazimierz, s. 247 („zarząd diecezji chełmińskiej objął z końcem stycznia 1719 r. przez pełnomocnika, a osobiście odbył ingres 30 VII tr.”); Szostkiewicz, Katalog biskupów obrzqdku łacińskiego, s. 417 (brak daty ingresu); Dola, Katalog arcybiskupów i biskupów, s. $260 \mathrm{nr} 43$ (brak daty ingresu); Die Bischöfe des Heiligen Römischen Reiches 1648 bis 1803, s. 36 (,übernahm Bokum die Leitung erst im Januar 1719 durch einen Prokurator, am 30 VII persönlich”); Nitecki, Biskupi Kościoła w Polsce, kol. 37 (brak daty ingresu).

${ }^{48}$ Diecezja chetmińska, s. 42-43 nr 32 (brak daty ingresu); P. Czaplewski, Działyński Kasper, biskup chetmiński (1639-1646), PSB, t. 6, s. 87 (brak daty ingresu); Szostkiewicz, Katalog biskupów obrzqdku łacińskiego, s. 442 (brak daty ingresu); Dola, Katalog arcybiskupów i biskupów, s. $260 \mathrm{nr} 33$ (brak daty ingresu); SBPN, t. 1, s. 367 (J. Poraziński) (brak daty ingresu); Die Bischöfe des Heiligen Römischen Reiches 1448 bis 1648, s. 141 (H. J. Karp) (brak daty ingresu); Nitecki, Biskupi Kościoła w Polsce, kol. 88 (brak daty ingresu); J. Szews, Stownik biograficzny ziemi lubawskiej 1244-2000, t. [1], Lubawa 2000, s. 56-57 (brak daty ingresu). 
ADP, C 13- [Acta curiae 1639-1646], k. 76r (Ingressus ad ecclesiam cathedralem Culmensem Illustrissimae Suae Celsitudinis); zob. również tamże, $k$. 14r-25v (opis ingresu w dniu $12 X$ 1636 do katedry w Chetmży biskupa chetmińskiego Jana Lipskiego)

[Anno 1640] Illustrissimus ac Reverendissimus Dominus Gasparus a Działyn Działynski, Dei et Apostolicae Sedis gratia episcopus Culmensis et Pomesaniae [...], die hodierna, quae fuit Dominica infra Octavam Corporis Christi, Junii decima [= 10 VI 1640], temporis festivitate caelique claritate serena, numeroso magnatum et aliorum nobilissimorum virorum comitatu illustri, in suam Culmsensem civitatem descendit [et] sponsam desideratam, ecclesiam cathedralem, feliciter salutavit [atque] limina visitavit.

Gembicki Jan biskup (Chetmża - Wtoctawek)

ingres $271 X 1653^{49}$

ADP, C 17 - Acta actorum institutionum, provisionum, erectionum, fundationum [...] aliarumque rerum coram Illustrissimo et Reverendissimo Domino, Domino Joanne Gembicki, Dei et Apostolicae Sedis gratia episcopo Culmensi et Pomesaniae, incipiendo a prima die Septembris in anno millesimo sexcentesimo quinquagesimo tertio ad diem ultimam Junii in anno millesimo sexcentesimo quinquagesimo quinto gestarum [1653-1655], s. 22-23 (Sabbatho XXVII Septembris [1653]. Die Translationis Sancti Stanislai. Ingressus Illustrissimi et Reverendissimi Domini episcopi ad ecclesiam cathedralem Culmsensem)

\section{5}

Geritz Józef Ambroży biskup (Warmia)

ingres 26 VI $1842^{50}$

AAWO, AB H 150, s. 6

Anno Domini 1842, Dominica Sanctissimae Trinitatis, quae fuit $22^{\underline{\mathrm{da}}}$ Maii, [ego Josephus Ambrosius Geritz] recepi sacrum pallium a Sua Santitate Gregorio P.P. XVI mihi, qua episcopo Varmiensi, concessum, in ecclesia cathedrali Culmensi ab eiusdem Ecclesiae episcopo Illustrissimo Domino Athanasio Sedlag. Anno eo-

${ }^{49}$ Diecezja chetmińska, s. 43 nr 34 (brak daty ingresu); A. Przyboś, Gembicki Jan (1602-1675), biskup kujawski, PSB, t. 7, s. 377 (brak daty ingresu); Szostkiewicz, Katalog biskupów obrzqdku tacińskiego, s. 452 (brak daty ingresu); Dola, Katalog arcybiskupów i biskupów, s. $260 \mathrm{nr} 35$ (brak daty ingresu); Die Bischöfe des Heiligen Römischen Reiches 1648 bis 1803, s. 148 (H. J. Karp) (brak daty ingresu); SBPN, t. 2, s. 31 (S. Cackowski) („objął diecezję [chełmińska] we wrześniu 1653 r.”); Nitecki, Biskupi Kościoła w Polsce, kol. 112 (brak daty ingresu).

${ }^{50}$ Dola, Katalog arcybiskupów i biskupów, s. $296 \mathrm{nr} 42$ (brak daty ingresu); Die Bischöfe der deutschsprachigen Länder 1785/1803 bis 1945, s. 245 („,die Inthronisation am 26 VI 1842 erfolgte”); Achremczyk, Marchwiński, Przeracki, Poczet biskupów warmińskich, s. 208 (,rządy diecezją objął 26 VI 1842 r.”); Stownik biograficzny kapituty warmińskiej, s. 68 (brak daty ingresu); Nitecki, Biskupi Kościoła w Polsce, kol. 114 (brak daty ingresu). 
dem, Dominica VI post Pentecosten, quae fuit $26^{\text {ta }}$ Junii, qua episcopus Varmiensis primum ingressum habui in ecclesiam meam cathedralem.

\section{6}

Kretkowski Feliks Ignacy biskup (Chetmża)

ingres 6 I $1724^{51}$

ADP, AKKCh A 49, k. 8v-9v (Ingressus ad cathedram [Culmensem] Excellentissimi, Illustrissimi et Reverendissimi Domini Felicis in Kretkow Kretkowski, Dei et Apostolicae Sedis gratia episcopi Culmensis et Pomesaniae [...] in Epiphania Domini Nostri Jesu Christi, die scilicet 6. mensis Januarii anno 1724)

\section{7}

Leszczyński Wacław biskup (Warmia - Gniezno)

ingres 2 VIII $1645^{52}$

AAWO, AK Acta Cap. 6 - Acta capitularia ab anno Domini 1638, die 21 Januarii, usque ad annum 1645, diem $2^{\text {dam }}$ Augusti, inclusive, $k .152$ v

Post longam Ecclesiae nostrae sui praesulis orbitatem, die 2. Augusti anno 1645 venit noster optatissimus Illustrissimus Reverendissimus Venceslaus comes a Leszno [Leszczyński], episcopus Varmiensis, pie cum cappis ab omnibus Admodum Reverendis Dominis praelatis et canonicis totoque Venerabili Capitulo Varmiensi obviatus, et in ecclesia cathedrali ab Admodum Reverendo Domino praeposito eleganti oratione humanissime exceptus.

${ }^{51}$ Diecezja chetmińska, s. 46 nr 42 (brak daty ingresu); Szostkiewicz, Katalog biskupów obrzadku łacińskiego, s. 493 (brak daty ingresu); Staszewski, Kretkowski Feliks Ignacy, s. 279 (brak daty ingresu); Dola, Katalog arcybiskupów i biskupów, s. $260 \mathrm{nr} 44$ (brak daty ingresu); Die Bischöfe des Heiligen Römischen Reiches 1648 bis 1803, s. 243 (brak daty ingresu); SBPN, t. 2, s. 503 (brak daty ingresu); Nitecki, Biskupi Kościoła w Polsce, kol. 227 (brak daty ingresu).

${ }^{52}$ Szostkiewicz, Katalog biskupów obrzqdku tacińskiego, s. 500-501 (brak daty ingresu); W. Czapliński, Leszczyński Wacław (1605-1666), biskup warmiński, potem prymas, PSB, t. 17, s. 149 („W sierpniu 1645 r. odbył uroczysty wjazd do Fromborka”); Dola, Katalog arcybiskupów i biskupów, s. 295 nr 30 (,,ingres w sierpniu 1645 r.”); Oracki, Stownik biograficzny Warmii, t. 2, s. 11 („2 VIII 1645 r. odbył ingres do katedry fromborskiej”); Die Bischöfe des Heiligen Römischen Reiches 1648 bis 1803, s. 270 (A. Triller) (brak daty ingresu); Achremczyk, Marchwiński, Przeracki, Poczet biskupów warmińskich, s. 146 (,uroczysty ingres do katedry fromborskiej odbył 2 VIII 1645 r."); Słownik biograficzny kapituły warmińskiej, s. 148 (A. Kopiczko) (brak daty ingresu); SBPN, t. 3, s. 51 (S. Achremczyk) (,ingres do katedry fromborskiej odbył się 2 VIII 1645 r.”); Nitecki, Biskupi Kościoła w Polsce, kol. 247 (brak daty ingresu). Por. Heide, Archiwum dawne i nowe, s. 105; Leo, Dzieje Prus, s. 528 („,pierwsze wejście miał 2 VIII w 1644 [sic!] roku”); Oesterrreich, Treter, Treter, Kronika lidzbarska, s. 135 (j.w.). 
Lipski Jan biskup (Chetmża - Gniezno)

ingres $12 \times 1636^{53}$

ADP, AKKCh A 46, k. 281v-282r

Illustrissimus et Reverendissimus Dominus, Dominus Joannes de Lipie Lipski, episcopus Culmensis et Pomesaniae nec non ecclesiae cathedralis Plocensis praepositus, in frequenti comitatu magnatum primo ad ecclesiam cathedralem, sponsam suam, Culmsam venit, ubi a Venerabili Capitulo et clero honorifice est exceptus et ab Admodum Reverendo Domino Georgio Alexandro Dorpowski, canonico et officiali generali Culmensi, oratione gratulatoria in ingressu templi est salutatus.

Małachowski Jan biskup (Chetmża - Kraków)

ingres $15 \mathrm{XI} 1676^{54}$

ADP, AKKCh A 65 - [Acta capituli Culmensis 1661-1690], s. 258 (Adventus Illustrissimi et Reverendissimi Domini, Domini episcopi [anno] 1676, die 15. Novembris)

Illustrissimus et Reverendissimus Dominus, Dominus Joannes de Małachovice Małachowski, episcopus Culmensis et Pomesaniae, abbas Mogilnensis, in frequenti comitatu primo ad ecclesiam cathedralem [Culmensem], sponsam suam, venit Culmsam [die 15. Novembris anni 1676], ubi a Venerabili Capitulo et clero honorifice est exceptus et a Perillustri et Admodum Reverendo Domino Joanne Chrisosthomo Olszowski, canonico Culmensi, oratione salutatoria in choro ecclesiae maiori [invitatus] est.

${ }^{53}$ Diecezja chetmińska, s. 42, nr 31 (brak daty ingresu); Szostkiewicz, Katalog biskupów obrzqdku łacińskiego, s. 499 (brak daty ingresu); H. E. Wyczawski, Lipski Jan (1589-1641), prymas Polski, PSB, t. 17, s. 423 (,,ingres do katedry w Chełmży odbył 12 X 1636 r.”); Dola, Katalog arcybiskupów i biskupów, s. $260 \mathrm{nr} 32$ (brak daty ingresu); SBPN, t. 3, s. 69 (A. Nadolny) („ingres do katedry w Chełmży odbył 12 X 1636 r.”); Die Bischöfe des Heiligen Römischen Reiches 1448 bis 1648, s. 431 (H.J. Karp) (brak daty ingresu); Nitecki, Biskupi Kościoła w Polsce, kol. 252 (,,ingres odbył 12 X 1636 r.”).

${ }^{54}$ Diecezja chetmińska, s. 44 nr 37 (brak daty ingresu); Szostkiewicz, Katalog biskupów obrzqdku łacińskiego, s. 510 (brak daty ingresu); H. E. Wyczawski, Małachowski Jan (1623-1699), referendarz, podkanclerzy koronny, biskup krakowski, PSB, t. 19, s. 397 (brak daty ingresu); Dola, Katalog arcybiskupów i biskupów, s. $260 \mathrm{nr} 39$ (brak daty ingresu); Die Bischöfe des Heiligen Römischen Reiches 1648 bis 1803, s. 292 (H. J. Karp) (brak daty ingresu); SBPN, t. 3, s. 155 (A. Nadolny) (,ingres do katedry w Chełmży odbył 15 XI 1676 r.”); Nitecki, Biskupi Kościoła w Polsce, kol. 279 (brak daty ingresu). 


\section{0}

Szczuka Kazimierz biskup (Chetmża)

ingres 18 II $1694^{55}$

ADP, C 25, k. 14r-15v (Ingressus Illustrissimi in dioecesim). Zob. również: ADP, AKKCh A 47, s. 110-111 (Die 18. Februarii [1694] ingressus Illustrissimi [Casimiri] Szczuka, episcopi [Culmensis], ad cathedram)

Recepta sacra expeditione, Illustrissimus et Reverendissimus Dominus episcopus Culmensis et Pomesaniae [Casimirus Szczuka] primis diebus Februarii Varsavia Culmam in suam dioecesim itineri accinctus, feliciter primo Starogrodum in arcem suam episcopalem die duodecima Februarii eiusdem anni millesimi sexcentesimi nonagesimi quarti pervenit, ubi sumpto prandio, eodem die, ipso iam vespere, Culmae ante portam a magistratu et incolis Culmensibus, cum oblatione clavium civitatis, salutatus [...] et in Seminarium Culmensem invitatus, ibidem residentiam suam episcopalem elegit. Inde vero post aliquot dierum moram Culmsam ad ecclesiam cathedralem, sponsam suam, divertit [...]. Tum demum die decima octava eiusdem mensis Februarii, ante portam civitatis Culmsensis similiter cum oblatione clavium civitatis per magistratum et incolas salutatus, lapideam Perillustris et Reverendissimi Domini Petri Rostkowski, nominati abbatis Mogilnensis, custodis Culmensis, canonici Varmiensis, intravit, in qua assumpto episcopali habitu, ad ecclesiam cathedralem, eodem ferme die quo annus septuagesimus secundus aetatis eius inchoabatur, pervenit et per obvium clerum cum collegio praelatorum et canonicorum saepedictae cathedralis ecclesiae pontificaliter ante maius altare adductus, ibidem [...] solitum iuramentum super Evangelium et statuta manus ponendo praestitit [...], tandem ad sedem seu cathedram episcopalem reductus, ibidem facta prius simili protestatione de possessione pacifica, per Perillustrem et Reverendissimum Dominum Thomam Bogoria Skotnicki, suffraganeum Culmensem, eleganti oratione nomine totius Venerabilis Capituli salutatus [est].

${ }^{55}$ Diecezja chetmińska, s. 45 nr 39 (,ingres 18 II 1694 r.”); Szostkiewicz, Katalog biskupów obrzqdku łacińskiego, s. 563 (brak daty ingresu); Dola, Katalog arcybiskupów i biskupów, s. 260 nr 41 (,,ingres 18 II 1694 r.”); Die Bischöfe des Heiligen Römischen Reiches 1648 bis 1803, s. 497 (,die Amtsübernahme in der Kathedrale zu Kulmsee fand am 18 II 1694 statt”); SBPN, t. 4, s. 309 (,12 II 1694 r. przyjechał do Starogrodu, a kilka dni później wjechał do Chełmży”); Nitecki, Biskupi Kościoła w Polsce, kol. 427 (,ingres odbył 18 II 1694 r.”). 